'Sanofi, Exploratory Unit, 91385 Chilly-Mazarin, France.

${ }^{2}$ Max Planck Institute of Psychiatry, Kraepelinstraße 10, D-80804 Munich, Germany.

Correspondence to G.G. e-mail:

guy.griebel@sanofi.com doi:10.1038/nrd3702

Published online 18 May 2012

\title{
Neuropeptide receptor ligands as drugs for psychiatric diseases: the end of the beginning?
}

\section{Guy Griebel ${ }^{1}$ and Florian Holsboer ${ }^{2}$}

Abstract | The search for novel drugs for treating psychiatric disorders is driven by the growing medical need to improve on the effectiveness and side-effect profile of currently available therapies. Given the wealth of preclinical data supporting the role of neuropeptides in modulating behaviour, pharmaceutical companies have been attempting to target neuropeptide receptors for over two decades. However, clinical studies with synthetic neuropeptide ligands have been unable to confirm the promise predicted by studies in animal models. Here, we analyse preclinical and clinical results for neuropeptide receptor ligands that have been studied in clinical trials for psychiatric diseases, including agents that target the receptors for tachykinins, corticotropin-releasing factor, vasopressin and neurotensin, and suggest new ways to exploit the full potential of these candidate drugs.

In 1998, the first positive clinical findings were reported for a synthetic neuropeptide receptor ligand in the treatment of a psychiatric disorder: the antidepressant effects of the substance $\mathrm{P}$ (also known as neurokinin 1) receptor antagonist MK-869 (aprepitant) in a placebo-controlled trial in patients with major depressive disorder (MDD) ${ }^{1}$. These findings fuelled basic research in the neuropeptide field and on neuropeptide receptor ligands in models of psychiatric diseases in particular. Moreover, neuropeptide receptors have become attractive therapeutic targets for the treatment of psychiatric disorders as a result of the rapid advances in understanding the structure and regulation of genes encoding neuropeptides, their transcription and translation, the characterization of their receptors, their genetic manipulation and the successful synthesis of both peptide and non-peptide receptor ligands $s^{2,3}$.

Prior to the results observed with aprepitant, research on neuropeptides in psychopharmacology had focused mainly on the involvement of the cholecystokinin (CCK) system in anxiety disorders, but clinical trials were unsuccessful $^{4,5}$ (BOX 1). During the past decade, drug discovery efforts using neuropeptide receptor ligands have focused on a limited number of peptides, including the tachykinins (such as neurokinin 1), corticotropin-releasing factor (CRF), vasopressin and neurotensin, despite the identification of numerous other neuropeptide systems. This is mainly because the pharmaceutical industry has successfully developed small non-peptidergic molecules with acceptable ADME (absorption, distribution, metabolism and excretion) properties for these systems, whereas for other neuropeptides (such as neuropeptide $\mathrm{Y}$, galanin and neuropeptide S) it has been very challenging to discover such compounds. In addition, many studies have shown that the pharmacological or genetic manipulation of these peptides modulates anxiety-, depression- or schizophrenia-related responses in animal models of psychiatric diseases. These and related findings have led to the clinical assessment of non-peptidergic receptor ligands in various psychiatric disorders.

Unfortunately, nearly 15 years after the publication of the antidepressant effect of aprepitant in a clinical trial, no drug acting at a neuropeptide system has made it to the market for the treatment of a psychiatric disease (although aprepitant was later approved for alleviating chemotherapy-induced nausea). Many Phase II/III trials of drugs targeting neuropeptide receptors have failed (TABLE 1). Furthermore, among the 40 drugs that are currently being tested in Phase II/III trials for schizophrenia, MDD or anxiety disorders, very few are compounds that target neuropeptide receptors (Supplementary information S1 (table)). This article reviews preclini$\mathrm{cal}$ and clinical findings on non-peptidergic ligands for neuropeptide receptors in psychiatric disorders, and provides possible explanations for the failure so far to develop small-molecule neuropeptide ligands for the 


\section{Box 1 | Research on the cholecystokinin system and anxiety}

Before the late 1990s, research on neuropeptides in psychopharmacology focused mainly on the involvement of the cholecystokinin (CCK) system in anxiety disorders. Initially, there was evidence that systemic administration of peptide CCK receptor agonists elicited panic-like symptoms in healthy volunteers and patients with social phobia, and potentiated the occurrence of panic attacks in patients with panic disorder. These effects were blocked by CCK2 receptor antagonists, but controlled clinical trials that have since been undertaken with CCK2 receptor antagonists in anxiety disorders have been unsuccessful ${ }^{4}$. Although the drugs were well tolerated, these studies failed to detect clinically significant differences between drugs and placebo.

The authors of these studies discussed several possible reasons that may have accounted for these negative findings, such as the poor pharmacokinetic characteristics of the drugs that were tested or the use of inadequate dosages. It has been suggested that second-generation antagonists with improved oral bioavailability might give more encouraging results. However, despite the variety of CCK2 receptor-targeted ligands ${ }^{5}$, no new CCK-based drugs are currently available for clinical use in psychiatric disorders. Perhaps pharmacokinetic parameters need to be further improved, both with respect to gastrointestinal absorption as well as blood-brain barrier penetration. Another issue is the specificity of the intervention. Although the anxiogenic effects of CCK receptor agonists are well founded, it is likely that CCK system overactivity may be a key factor in only a subset of patients with anxiety disorders.

\section{Hypothalamic-}

pituitary-adrenal axis

A tightly linked, interdependent endocrine structure that

comprises a major peripheral part of the stress system,

the main function of which is to maintain basal and

stress-related homeostasis.

Neurogenesis

The growth and development of nerve tissues. treatment of anxiety, MDD and schizophrenia. The focus of this article is on tachykinins, CRF, vasopressin and neurotensin, as drugs interacting with these systems have reached Phase II/III trials.

\section{Tachykinins}

The mammalian tachykinins are a group of neuropeptides that include substance $\mathrm{P}$, neurokinin A (NKA; also known as tachykinin precursor 1 ) and neurokinin $B$ (NKB; also known as tachykinin 3$)^{6}$. These tachykinins are widely distributed in the central nervous system (CNS) but they have distinct expression patterns. The highest concentrations of NKB are found in cortical areas, whereas substance $P$ and NKA share a more similar distribution pattern, with strong expression in the spinal cord and in structures that are implicated in emotional processes (for example, the nucleus accumbens, septum and the amygdala). At a cellular level, substance P and NKA are mostly colocalized in neurons and interneurons with glutamate, GABA ( $\gamma$-aminobutyric acid), monoamines or acetylcholine.

The biological actions of substance P, NKA and NKB are mediated via the activation of $G$ protein-coupled seven-transmembrane domain receptors designated as tachykinin receptor 1 (TACR1; also known as the $\mathrm{NK}_{1}$ receptor), TACR2 (also known as the $\mathrm{NK}_{2}$ receptor) and TACR3 (also known as the $\mathrm{NK}_{3}$ receptor), respectively ${ }^{7}$. Both $\mathrm{NK}_{1}$ and $\mathrm{NK}_{3}$ receptors are widely distributed in the CNS, whereas the $\mathrm{NK}_{2}$ receptor is found in the smooth muscle of the gastrointestinal, respiratory and urinary tracts, but it has also been located in discrete regions of the rodent CNS, such as the prefrontal cortex and the hippocampus ${ }^{8}$ (FIG. 1a). Tachykinins bind to various receptor isoforms with different affinities for the endogenous peptides and with tissue-specific expression patterns. Several tachykinin receptor antagonists have a higher affinity for the guinea pig and human receptor isoforms than for the rat and mouse receptor isoforms ${ }^{9}$. This species heterogeneity, which has been noted for $\mathrm{NK}_{1}$ and $\mathrm{NK}_{3}$ receptors, but not for $\mathrm{NK}_{2}$ receptors, has had a major impact on the development of specific antagonists for these receptors, as it required the development of suitable behavioural models in atypical species such as guinea pigs and gerbils to characterize their effects ${ }^{10-12}$.

$\mathrm{NK}_{1}$ receptor antagonists. Since the first non-peptide $\mathrm{NK}_{1}$ receptor antagonist, CP-96345, was described in 1991 (REF. 13), a plethora of highly selective, highaffinity, brain-penetrant, non-peptide antagonists for this receptor have been synthesized ${ }^{14}$. Studies in animals have shown that $\mathrm{NK}_{1}$ receptor antagonists elicit robust antidepressant-like activity, but inconsistent results were reported in classical models of anxiety ${ }^{3,14,15}$ (FIG. 2). Several mechanisms for the modulatory role of $\mathrm{NK}_{1}$ receptor antagonists in affective behaviour have been suggested. Initially, it was thought that the substance $\mathrm{P}-\mathrm{NK}_{1}$ receptor system directly modulated the mood response to stressful stimuli - that is, independently of other neurotransmitter pathways ${ }^{1}$ - but an increasing number of studies suggest that the effects of $\mathrm{NK}_{1}$ receptor antagonists may involve complex interactions with the hypothalamic-pituitary-adrenal axis (HPA axis), neurotransmitter systems and/or hippocampal neurogenesis ${ }^{14}$. For example, $\mathrm{NK}_{1}$ receptor antagonists have been shown to enhance serotonin and noradrenaline transmission via presynaptic mechanisms. Such effects are similar, although not identical, to those of current antidepressants ${ }^{16}$.

Effects that were similar to those observed with aprepitant in patients with depression were subsequently observed with three other $\mathrm{NK}_{1}$ receptor antagonists: L-759274 (REF. 17), CP-122721 (REF. 18) and casopitant ${ }^{19}$. However, in subsequent Phase IIb and Phase III trials, aprepitant was inactive $e^{20,21}$, and a Phase IIa trial of casopitant was inconclusive ${ }^{22}$. For orvepitant, an $\mathrm{NK}_{1}$ receptor antagonist developed by GlaxoSmithKline, Phase IIb trials had to be terminated before completion owing to the occurrence of isolated events of seizures (TABLE 1).

Several Phase II studies have been conducted using $\mathrm{NK}_{1}$ receptor antagonists in patients suffering from social anxiety disorder (SAD), but the results have again been inconsistent. Although initial proof-of-concept studies of AV608 and GR205171 - two $\mathrm{NK}_{1}$ receptor antagonists developed by Avera Pharmaceuticals and GlaxoSmithKline, respectively - in SAD suggested the efficacy of these antagonists in alleviating anxiety symptoms, the results obtained with AV608 were not replicated in a second small Phase IIa trial at comparable doses (that is, $0.1 \mathrm{mg}$ and $1 \mathrm{mg}$ ) or in a large Phase IIb, double-blind, placebo-controlled trial (at a dose of $160 \mathrm{mg}$ ), despite a significant increase in exposure time ${ }^{23}$. Moreover, a clinical trial using LY686017 - an $\mathrm{NK}_{1}$ receptor antagonist developed by Lilly - in outpatients suffering from SAD was unable to establish a signal for clinical efficacy at plasma concentrations that were above the level expected to produce maximal $\mathrm{NK}_{1}$ receptor occupancy in the brain ${ }^{24}$. The effects of 
Table 1 | Completed Phase II and III trials with neuropeptide receptor ligands in psychiatric diseases

\begin{tabular}{|c|c|c|c|c|c|}
\hline Compound & Doses & Study & $\begin{array}{l}\text { Indication: primary } \\
\text { efficacy measures }\end{array}$ & Results & Refs \\
\hline \multicolumn{6}{|c|}{ Neurokinin $1\left(N K_{1}\right)$ receptor antagonists } \\
\hline Orvepitant & $30 \mathrm{mg}$ and $60 \mathrm{mg}$ & Phase Ilb, double-blind, placebo-controlled trial & MDD: HAM-D & Terminated & * \\
\hline Orvepitant & $30 \mathrm{mg}$ and $60 \mathrm{mg}$ & Phase Ilb, double-blind, placebo-controlled trial & MDD: HAM-D & Terminated & * \\
\hline Orvepitant & $60 \mathrm{mg}$ & Phase Ilb, double-blind, placebo-controlled trial & PTSD: CAPS & Terminated & * \\
\hline AV608 & $160 \mathrm{mg}$ & Phase Ilb, double-blind, placebo-controlled trial & Social anxiety: LSAS & Inactive & 23 \\
\hline AV608 & $0.1 \mathrm{mg}$ and $1 \mathrm{mg}$ & Phase lla trial & Social anxiety & Inactive & 23 \\
\hline LY686017 & $50 \mathrm{mg}$ & $\begin{array}{l}\text { Phase Ila placebo-controlled trial versus } \\
\text { paroxetine }(20 \mathrm{mg})\end{array}$ & Social anxiety: LSAS & Inactive & 24 \\
\hline GR205171 & $5 \mathrm{mg}$ & Phase lla, double-blind, placebo-controlled trial & PTSD: CAPS & Inactive & 25 \\
\hline GR205171 & $5 \mathrm{mg}$ & $\begin{array}{l}\text { Phase Ila placebo-controlled trial versus } \\
\text { citalopram ( } 40 \mathrm{mg})\end{array}$ & $\begin{array}{l}\text { Social anxiety: LSAS, } \\
\text { CGI, STAI }\end{array}$ & $\begin{array}{l}\text { Improvement in all primary } \\
\text { efficacy parameters }\end{array}$ & 178 \\
\hline CP-122721 & $10 \mathrm{mg}$ and $30 \mathrm{mg}$ & $\begin{array}{l}\text { Phase Ila placebo-controlled trial versus } \\
\text { fluoxetine }(20 \mathrm{mg})\end{array}$ & MDD:HAM-D & Improvement in HAM-D & 18 \\
\hline Casopitant & $30 \mathrm{mg}$ and $80 \mathrm{mg}$ & Phase Ilb, double-blind, placebo-controlled trial & MDD: HAM-D & $\begin{array}{l}\text { Improvement with } 80 \mathrm{mg} \\
\text { dose }\end{array}$ & 19 \\
\hline Casopitant & $120 \mathrm{mg}$ & $\begin{array}{l}\text { Phase lla placebo-controlled trial versus } \\
\text { paroxetine }(30 \mathrm{mg})\end{array}$ & MDD: HAM-D & Inconclusive & 19 \\
\hline Aprepitant & $300 \mathrm{mg}$ & $\begin{array}{l}\text { Phase Ilb placebo-controlled trial versus } \\
\text { paroxetine }(20 \mathrm{mg})\end{array}$ & MDD: HAM-A, HAM-D & $\begin{array}{l}\text { Improvement in all primary } \\
\text { efficacy parameters }\end{array}$ & 1 \\
\hline Aprepitant & $160 \mathrm{mg}$ & $\begin{array}{l}\text { Phase Ilb placebo-controlled trial versus } \\
\text { paroxetine }(20 \mathrm{mg})\end{array}$ & MDD: HAM-D & Inactive & 20 \\
\hline Aprepitant & $80 \mathrm{mg}$ and $160 \mathrm{mg}$ & $\begin{array}{l}\text { Phase Ilb placebo-controlled trial versus } \\
\text { paroxetine }(20 \mathrm{mg})\end{array}$ & MDD: HAM-D & Inactive & 20 \\
\hline Aprepitant & $400 \mathrm{mg}$ & $\begin{array}{l}\text { Phase Ila placebo-controlled trial versus } \\
\text { haloperidol }\end{array}$ & Schizophrenia & Inactive & 26 \\
\hline \multicolumn{6}{|c|}{$\mathrm{NK}_{2}$ receptor antagonist } \\
\hline Saredutant & $\begin{array}{l}30 \mathrm{mg}, 100 \mathrm{mg} \text { and } \\
300 \mathrm{mg}\end{array}$ & $\begin{array}{l}\text { Phase Illb placebo-controlled trial versus } \\
\text { fluoxetine ( } 20 \mathrm{mg})\end{array}$ & MDD: HAM-D & Inactive & $\S$ \\
\hline Saredutant & $100 \mathrm{mg}$ & $\begin{array}{l}\text { Phase III placebo-controlled trial versus } \\
\text { paroxetine }(20 \mathrm{mg})\end{array}$ & MDD: HAM-D & Inactive & $\S$ \\
\hline Saredutant & $100 \mathrm{mg}$ & $\begin{array}{l}\text { Phase III placebo-controlled trial versus } \\
\text { paroxetine }(20 \mathrm{mg})\end{array}$ & MDD: HAM-D & Inactive & $\S$ \\
\hline Saredutant & $100 \mathrm{mg}$ & $\begin{array}{l}\text { Phase III placebo-controlled trial versus } \\
\text { paroxetine }(20 \mathrm{mg})\end{array}$ & MDD: HAM-D & Improvement in HAM-D & $\S$ \\
\hline Saredutant & $100 \mathrm{mg}$ & $\begin{array}{l}\text { Phase III placebo-controlled trial versus } \\
\text { escitalopram ( } 10 \mathrm{mg})\end{array}$ & MDD: HAM-D & Inconclusive & $\S$ \\
\hline Saredutant & $100 \mathrm{mg}$ & $\begin{array}{l}\text { Phase III placebo-controlled trial versus } \\
\text { paroxetine }(20 \mathrm{mg})\end{array}$ & MDD: HAM-D & Improvement in HAM-D & $\S$ \\
\hline Saredutant & $100 \mathrm{mg}$ & $\begin{array}{l}\text { Phase III placebo-controlled trial versus } \\
\text { escitalopram ( } 10 \mathrm{mg})\end{array}$ & GAD: HAM-A & Inconclusive & $\S$ \\
\hline Saredutant & $30 \mathrm{mg}$ and $100 \mathrm{mg}$ & Phase III placebo-controlled trial & GAD: HAM-A & Inactive & $\S$ \\
\hline Saredutant & $100 \mathrm{mg}$ & $\begin{array}{l}\text { Phase III placebo-controlled trial versus } \\
\text { escitalopram }(10 \mathrm{mg})\end{array}$ & GAD: HAM-A & Inactive & $\S$ \\
\hline
\end{tabular}




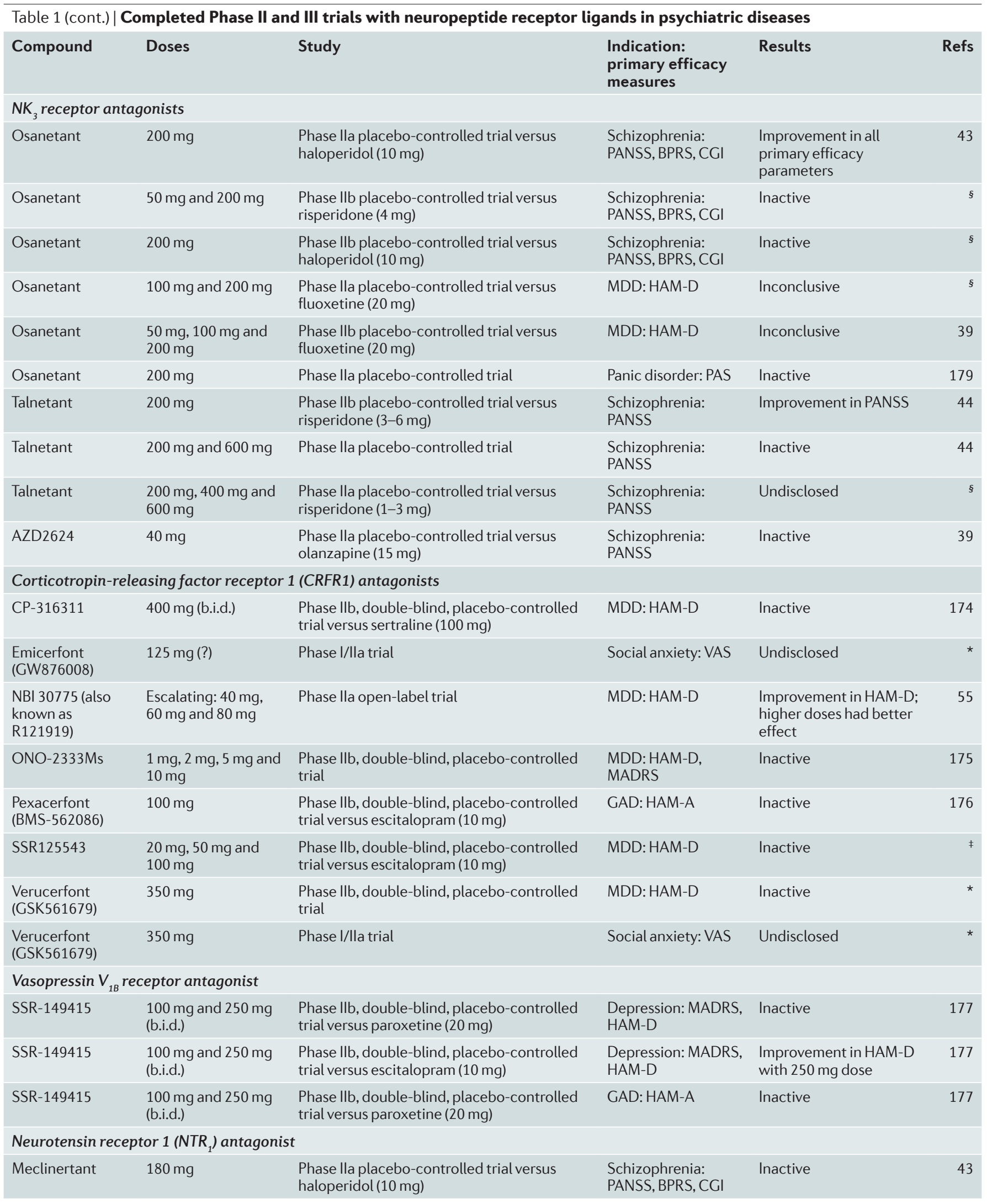

b.i.d., twice daily; BPRS, brief psychiatric rating scale; CAPS, clinician administered PTSD scale; CGI, clinical global impressions; GAD, generalized anxiety disorder; HAM-A, Hamilton anxiety rating scale; HAM-D, Hamilton depression rating scale; LSAS, Liebowitz social anxiety scale; MADRS, Montgomery-Åsberg depression rating scale; MDD, major depressive disorder; PANSS, positive and negative syndrome scale; PAS, panic and agoraphobia scale; PTSD, post-traumatic stress disorder; STAI, Spielberger state trait anxiety inventory; VAS, visual analog scale. *See the GSK Clinical Study Register on the GlaxoSmithKline (GSK) website. ¥See the 28 April 2011 press release on the Sanofi website. ${ }^{\S}$ See the ClinicalTrials.gov website. 
a Neurokinins

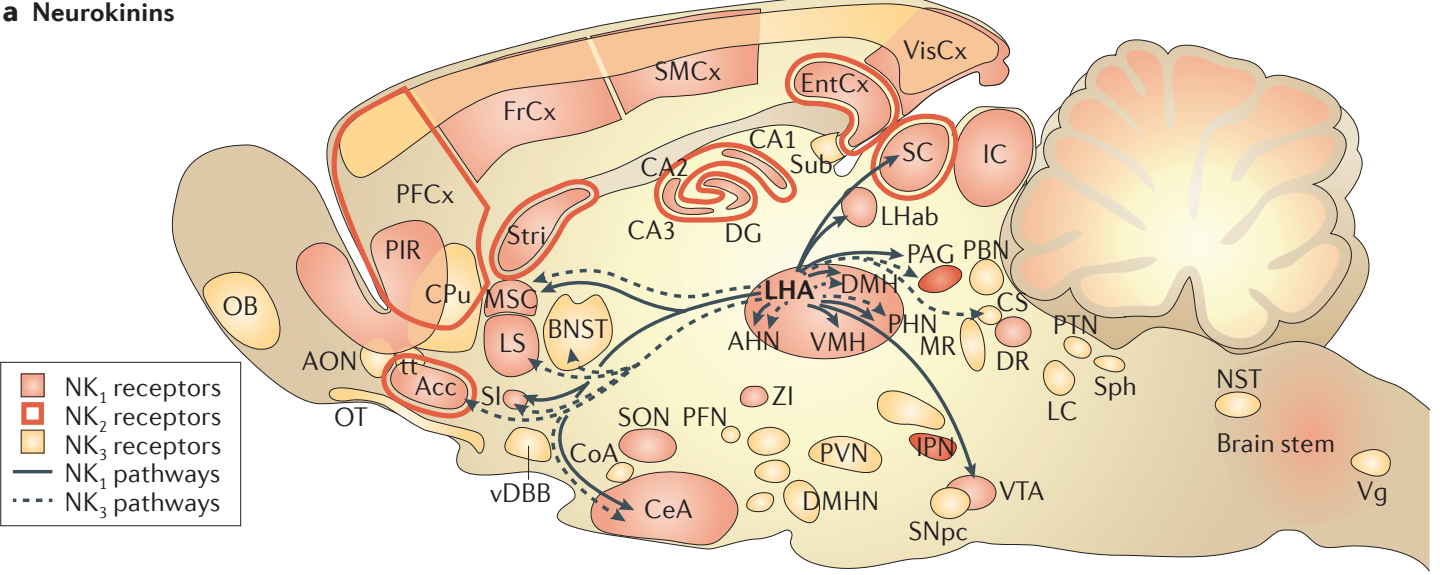

b Corticotropin-releasing factor

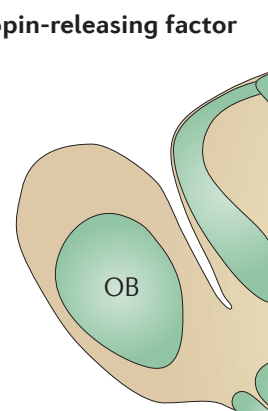

CRFR1

... Hypothalamic pathways

- Central pathways
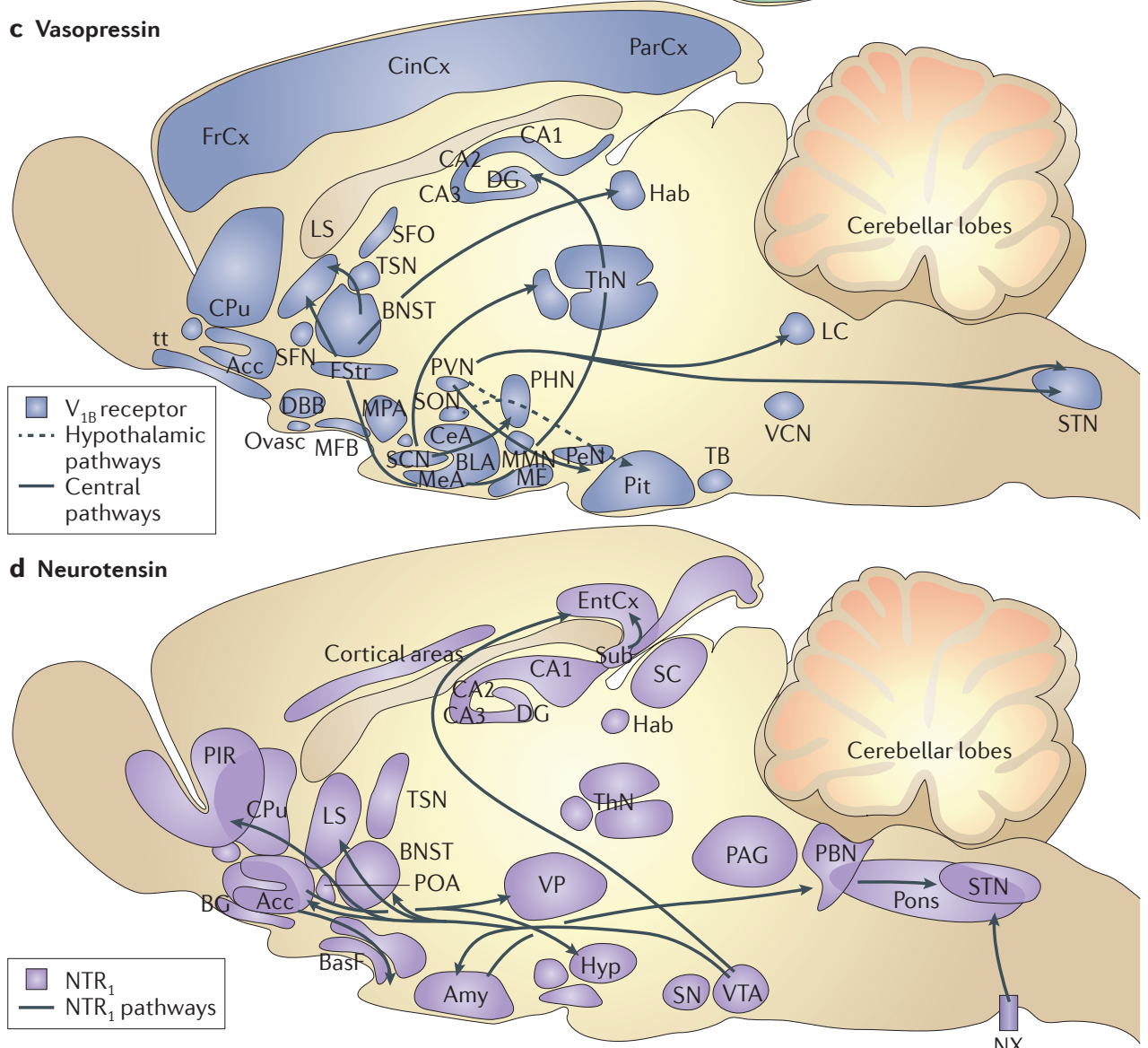
$\triangleleft$ Figure 1 | Neurokinin, corticotropin-releasing factor, vasopressin and neurotensin pathways (and their receptors) in regions of the rat brain. The figures show that neurokinin and its receptors ( $\mathrm{NK}_{1}$ receptor, $\mathrm{NK}_{2}$ receptor and $\mathrm{NK}_{3}$ receptor) (part a), corticotropin-releasing factor (CRF) and its receptor (CRF receptor 1 (CRFR1)) (part b), vasopressin and its receptor (vasopressin $\mathrm{V}_{1 \mathrm{~B}}$ receptor) (part c) as well as neurotensin and its receptor (neurotensin receptor $\left.1\left(\mathrm{NTR}_{1}\right)\right)$ (part $\mathbf{d}$ ) are densely localized in areas that process emotion (such as amygdala nuclei), the response to stress (such as hypothalamic nuclei) and/or cognition (such as hippocampal nuclei and cortical areas). $A_{1}$, noradrenaline-containing cell group $A 1 ; A_{5}$, noradrenalinecontaining cell group A5; ac, anterior commissure; Acc, accumbens nucleus; AHA, anterior hypothalamic area; $\mathrm{AHN}$, anterior hypothalamic nucleus; Amy, amygdala; AON, anterior olfactory nucleus; BasF, basal forebrain; BG, basal ganglia; BLA, basolateral amygdala; BNST, bed nucleus of the stria terminalis; CA1, hippocampal field CA1; CC, corpus callosum; CeA, central amygdala; CG, central grey matter; CinCx, cingulate cortex; CoA, cortical amygdaloid nucleus; $\mathrm{CL}$, colliculi; $\mathrm{CPu}$, caudate putamen; CS, superior central nucleus raphe; DBB, diagonal band of Broca; DG, dentate gyrus; DMH, dorsomedial hypothalamus; DMHN, dorsomedial hypothalamic nucleus; DR, dorsal raphe; DVC, dorsal motor nucleus of the vagus; EntCx, entorhinal cortex; FrCx, frontal cortex; FStr, fundus striati; Hab, medial habenula; Hyp, hypothalamic nucleus; IC, inferior colliculus; IPN, interpeduncular nucleus; LC, locus coeruleus; LDT, laterodorsal tegmental nucleus; LH, lateral hypothalamus; LHA, lateral hypothalamic area; LHab, lateral habenula; LS, lateral septum; ME, median eminence; MeA, median amygdala; MFB, medial forebrain bundle; MMN, medial mammillary nucleus; MPA, medial proptic area; MR, median raphe; MSC, medial septal complex; MVN, medial vestibular nucleus; NST, nucleus of the solitary tract; $\mathrm{NX}$, dorsal motor nucleus of the vagus; OB, olfactory bulb; OT, olfactory tubercle; Ovasc, organum vasculosum laminae terminalis; PAG, periaqueductal grey; $\mathrm{ParCx}$, parietal cortex; PBN, parabrachial nucleus; PeN, periventricular hypothalamic nucleus; PFCx, prefrontal cortex; PFN, parafascicular thalamic nucleus; PHN, posterior hypothalamic nucleus; PIR, piriform area; Pit, anterior pituitary; POA, preoptic area; POR, perioculomotor nucleus; PTN, paratrigeminal nucleus; PVN, paraventricular nucleus of the hypothalamus; Sub, subiculum; SC, superior colliculus; SCN, suprachiasmatic nucleus; Sep, septum; SFN, septofimbrial nucleus; SFO, subfornical organ; SI, substantia innominata; SMCx, sensorimotor cortex; SNpc, substantia nigra pars compacta; SON, supraoptic nucleus; Sph, sphenoid nucleus; STN, solitary tract nucleus; Stri, striatum; TB, trapezoid body; ThN, thalamic nucleus; TSN, triangular septal nucleus; tt, taenia tecta; $V C N$, ventral cochlear nucleus; vDBB, nucleus of the ventrical limb of the diagonal band; $\mathrm{Vg}$, vagus nerve; $\mathrm{Vis} C \mathrm{x}$, visual cortex; $\mathrm{VMH}$, ventromedial nucleus hypothalamus; VP, ventral pallidum; VTA, ventral tegmental area; $\mathrm{ZI}$, zone inserta.

Cyclic AMP response element-binding protein

A cellular transcription factor that binds to certain DNA sequences called cyclic AMP response elements, thereby increasing or decreasing the transcription of downstream genes.
GR205171 were also examined in patients with posttraumatic stress disorder (PTSD), but the drug did not meet the primary efficacy end point, although it significantly improved hyperarousal symptoms ${ }^{25}$. Finally, an exploratory placebo- and haloperidol-controlled clinical trial with aprepitant was conducted in inpatients with schizophrenia. The results indicate that this compound lacks efficacy as a primary form of therapy for acute psychosis $^{26}$.

The inconsistent findings with $\mathrm{NK}_{1}$ receptor antagonists in MDD and anxiety disorders have been ascribed to several factors, such as a high placebo effect in some of the trials, poor brain penetration and receptor occupation, suboptimal pharmacokinetic and pharmacodynamic (PK/PD) properties and/or lack of selectivity of some compounds for the human $\mathrm{NK}_{1}$ receptor ${ }^{20,21,27}$. However, aprepitant, GR205171 and LY686017 failed to be efficacious despite having proven excellent drug exposure to the CNS $\mathrm{NK}_{1}$ receptor target; furthermore, aprepitant was ineffective in large, blinded, randomized controlled trials in which a known active antidepressant was effective. The discrepancy in the findings between the initial Phase II trial and the subsequent Phase III studies of aprepitant was also suggested to be due to the recruitment, in the former study, of a subgroup of MDD patients with an anxiety component who were preferentially responsive to $\mathrm{NK}_{1}$ receptor blockade ${ }^{28-30}$.

$\mathrm{NK}_{2}$ receptor antagonists. The search for $\mathrm{NK}_{2}$ receptor antagonists has resulted in the discovery of several classes of compounds. The first reported non-peptidergic $\mathrm{NK}_{2}$ receptor antagonist, saredutant $(\mathrm{SR} 48968)^{31}$, exhibited anxiolytic-like effects in several animal models. These effects, however, were generally weaker than those displayed by benzodiazepines ${ }^{3,27}$. In addition, saredutant exhibited antidepressant-like effects in several rodent models, and these effects were comparable to those of current monoamine-based antidepressants ${ }^{32-34}$. Although the mechanisms underlying these effects remain largely unknown, it is noteworthy that $\mathrm{NK}_{2}$ receptor blockade does not influence the basal levels of neurotransmitters involved in the pathophysiology of stress, but it does attenuate the stress-induced increase in the firing of neurons in the locus coeruleus and the release of noradrenaline in the prefrontal cortex ${ }^{32}$.

Furthermore, chronic treatment with saredutant upregulated levels of cyclic AMP-responsive elementbinding protein and promoted neurogenesis in the hippocampus after chronic stress exposure in mice 6 . Similar effects were observed with current antidepressant treatments. Together, these results suggested that selective $\mathrm{NK}_{2}$ receptor antagonists could be used for the treatment of depression and anxiety disorders.

Saredutant is the only $\mathrm{NK}_{2}$ receptor antagonist that has reached clinical Phase IIb and Phase III trials (TABLE 1). Two of these studies, one in MDD and the other in generalized anxiety disorder (GAD), were inconclusive as the positive control drug was inactive. In other MDD trials, saredutant significantly improved primary efficacy parameters in two studies but it was inactive in three other studies. Moreover, the magnitude of the effects of saredutant across key end points was generally smaller than the effects of paroxetine, which was used as a comparator. In other GAD trials, saredutant failed to improve any of the primary and secondary efficacy end points compared with placebo-treated patients or patients who received the comparator, escitalopram. It is noteworthy that saredutant was well tolerated in all of these studies.

To explain the weak efficacy of saredutant in clinical trials, it was suggested that the plasma concentrations of the drug in humans were too low to achieve therapeutic efficacy ${ }^{6}$. In mice, saredutant produced maximal efficacy in depression models at doses of $10 \mathrm{mg}$ per $\mathrm{kg}$ and $30 \mathrm{mg}$ per $\mathrm{kg}$ when it was orally administered acutely. At these doses, the $\mathrm{C}_{\max }$ (maximum plasma concentration) ranged from $223 \mathrm{ng}$ per $\mathrm{ml}$ to $1,390 \mathrm{ng}$ per $\mathrm{ml}$. In humans, following 10 to 14 days of saredutant treatment (at a dose of $100 \mathrm{mg}$ per day), the $\mathrm{C}_{\max }$ at the steady-state plasma concentration was far lower, ranging between $28 \mathrm{ng}$ per $\mathrm{ml}$ and $49 \mathrm{ng}$ per $\mathrm{ml}$ (C. Cohen, personal communication). Interestingly, although the drug had 
limited or no efficacy in classical animal models of anxiety, such as the elevated plus-maze test, it reduced anxiety-like behaviour following traumatic stress exposure, which suggests that PTSD - but not GAD - may be more sensitive to $\mathrm{NK}_{2}$ receptor antagonism ${ }^{35}$.

In summary, although saredutant showed promising effects in animal models of depression, and some (albeit less promising) effects in models of anxiety, these did not translate into significant clinical activity. This could be due to the fact that current animal models that are developed and validated for monoamine- or aminoacid-based drugs are poor predictors of clinical efficacy for new drugs with different mechanisms of action.

$\mathrm{NK}_{3}$ receptor antagonists. Osanetant was the first potent non-peptide $\mathrm{NK}_{3}$ receptor antagonist described in the literature ${ }^{36}$. It was soon followed by the development of various novel chemical classes of potent, competitive and selective non-peptide antagonists for the human $\mathrm{NK}_{3}$ receptor. Currently, there are more than 80 patent applications for compounds claimed as $\mathrm{NK}_{3}$ receptor antagonists $^{37-40}$. Experimental evidence indicates that $\mathrm{NK}_{3}$ receptors have a key role in dopaminergic function in the midbrain. $\mathrm{NK}_{3}$ receptors are found predominantly in the substantia nigra and the ventral tegmental area regions of the brain that have a high concentration of dopaminergic neurons ${ }^{41}$.

Because excessive dopaminergic function is thought to be responsible for some of the symptoms of schizophrenia, it was hypothesized that NKB, the endogenous peptide for $\mathrm{NK}_{3}$ receptors, may be involved in the pathophysiology of this condition ${ }^{37,39,42}$. This idea has been supported by a few studies that investigated the behavioural effects of $\mathrm{NK}_{3}$ receptor antagonists in animal models that are predictive of antipsychotic activity ${ }^{37,42}$. Selective $\mathrm{NK}_{3}$ receptor antagonists have also been tested in several animal models of anxiety and depression, but the findings are equivocal and do not provide a clear picture on the antidepressant and anxiolytic potential of these drugs $\mathrm{s}^{3,27}$.

Several $\mathrm{NK}_{3}$ receptor antagonists have been evaluated in patients with schizophrenia (TABLE 1). Preliminary data in a special study protocol termed 'Metatrial' indicated that osanetant, which was well tolerated, had an antipsychotic efficacy profile that was similar to that of haloperidol ${ }^{43}$. However, subsequent larger trials of osanetant failed to demonstrate efficacy in patients with schizophrenia, leading to discontinuation of the development of the drug in 2005. Several Phase II trials have been performed with another $\mathrm{NK}_{3}$ receptor antagonist, talnetant, in schizophrenia. An initial placebo-controlled study revealed that talnetant reduced the positive and negative syndrome scale (PANSS) score to a similar extent as the antipsychotic drug risperidone, but this effect was not replicated in subsequent trials ${ }^{44}$ so development was discontinued. More recently, AstraZeneca presented findings of another $\mathrm{NK}_{3}$ receptor antagonist, AZD-2624, which was also inactive in a Phase IIa trial for schizophrenia ${ }^{39}$. Osanetant was also tested in patients with panic disorder or $\mathrm{MDD}^{39}$, but the effect of the drug was not significantly different from placebo.
The available clinical findings with selective $\mathrm{NK}_{3}$ receptor antagonists in psychiatric diseases, in particular schizophrenia, have not convincingly established that blockade of this neuropeptide receptor may be sufficient to improve these clinical conditions. It has been suggested that the suboptimal pharmacokinetic characteristics of osanetant and talnetant, such as limited brain penetration, may account at least in part for their poor efficacy in clinical trials ${ }^{41}$. However, at least in the case of talnetant, it was established that the drug penetrates the brain ${ }^{45}$.

In summary, despite the sometimes extensive and compelling preclinical data and early clinical evidence suggesting that tachykinin receptor antagonists may be useful for the treatment of MDD, anxiety disorders and schizophrenia, clinical results have been disappointing. Although in some cases the compounds may have had suboptimal PK/PD properties, compounds with improved PK/PD parameters for which brain penetration was established also failed to show efficacy. Combining tachykinin receptor antagonists with established therapeutics might enhance the tolerability of the first-line treatments or improve their therapeutic efficacy ${ }^{27}$. However, two recent double-blind, placebocontrolled studies using saredutant in combination with escitalopram or paroxetine in patients with MDD did not support this idea. Patients who received the combination did not show an improvement in the severity of depressive symptoms in comparison with patients who received paroxetine or escitalopram alone (G.G., unpublished observations). Given the results discussed above, it is not surprising that pharmaceutical companies have considerably reduced or abandoned research and development of tachykinin receptor ligands for the treatment of CNS disorders.

\section{Corticotropin-releasing factor}

Thirty years ago, Vale and colleagues ${ }^{46}$ isolated CRF (also termed corticotropin-releasing hormone (CRH); $\mathrm{CRH}$ is the official symbol for the gene encoding CRF) from sheep hypothalami. Its chemical and biological characterization, including neuroendocrine and behavioural analyses, revealed that CRF is the major physiological regulator of stress ${ }^{46}$. There are three paralogues of CRF: urocortin 1 (UCN1), UCN2 (also known as stresscopin-related peptide) and UCN3 (also known as stresscopin $)^{47}$. All four neuropeptides bind to at least two receptors: CRF receptor 1 (CRFR1) and CRFR2. Outside the brain, CRFR1 is expressed at high density in corticotropic cells producing corticotropin (also known as adrenocorticotropic hormone (ACTH)). The high density of CRFRs at the pituitary enables the stress axis to secrete stress hormones even if CRFRs in the brain are already occupied.

As illustrated in FIG. 1b, CRFR1 (specifically the CRFR1a splice variant) is centrally expressed in neocorti$\mathrm{cal}$ areas, the hippocampus, basolateral amygdala, ventral tegmental area, pontine grey lateral dorsal tegmentum and peduncolopontine tegmental nucleus ${ }^{48}$. The basolateral nucleus of the amygdala is a key area of the brain in the context of psychopharmacology as it coordinates fear and anxiety, and its overactivity had been linked to 


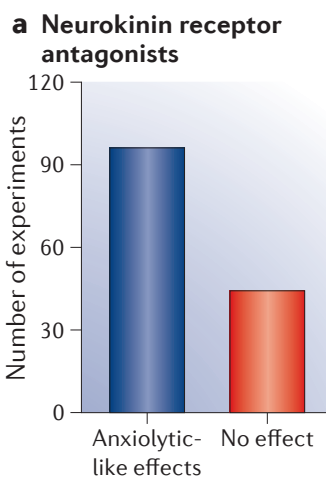

b CRFR1 antagonists

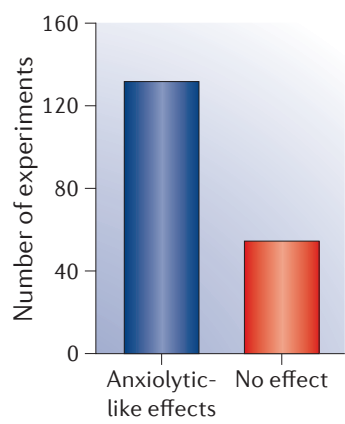

c $\mathrm{V}_{1 \mathrm{~B}}$ antagonists

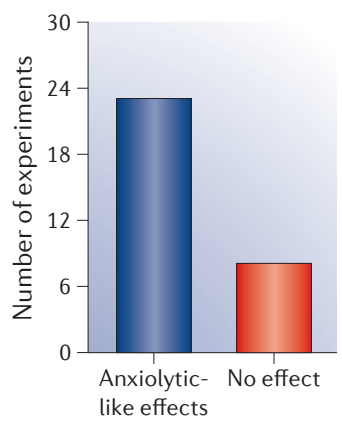

Figure 2 | Outcome of experiments that investigated the effects of synthetic neurokinin receptor, CRFR1 and $\mathrm{V}_{1 \mathrm{~B}}$ receptor antagonists in animal models of anxiety from 1990 to 2011. The graphs (parts a-c) show that synthetic antagonists of neurokinin receptors, corticotropin-releasing factor receptor 1 (CRFR1) and vasopressin $\mathrm{V}_{1 \mathrm{~B}}$ receptor produced anxiolytic-like effects in about two-thirds of the studies.

the onset and course of depression. The important role of CRF-CRFR1 signalling in anxiety and other stress-related conditions has been highlighted in studies showing high levels of CRF in mice in which innate high anxiety was established by selective breeding and by the suppression of anxiety-like behaviour after the administration of CRFR1 antagonists ${ }^{49}$. CRFR2 is abundant in peripheral tissues (for example, the heart) and is also found at a high density in the septum, hypothalamus and dorsal raphe nucleus ${ }^{50}$. CRFR1 and CRFR2 have distinct neuroanatomical distributions and pharmacological profiles ${ }^{51}$ : CRF is the predominant endogenous ligand for CRFR1; UCN2 and UCN3 are selective CRFR2 ligands; and UCN1 binds to both subtypes with comparable affinity.

One feature that increases the complexity of signalling by CRF and its paralogues is that their biological activity is influenced by CRF binding protein. This glycoprotein is highly expressed in many tissues including the brain, where it binds to all four CRFR ligands with a high affinity, thus competing with receptor binding and subsequent signalling ${ }^{52}$. Furthermore, the CRF system involves brain-area-specific differences in downstream signalling that include (among others) the nuclear factor- $\kappa B$ pathway as well as the extracellular signalregulated kinase (ERK)-mitogen-activated protein kinase pathway ${ }^{53}$. In hippocampal CA1 and CA3 pyramidal cells and in the basolateral amygdala, for example, CRF induces strong ERK1 and ERK2 activation, but this was not seen in mice in which the Crhrl gene (which encodes CRFR1) had been conditionally deleted in the forebrain and limbic system ${ }^{54}$.

Clinical and basic research over the past three decades

Forced swim test A screening model of depression in rodents that measures immobility in a beaker half-filled with water as a measure of despair

behaviour. This test has been widely used in the discovery of monoamine-based drugs because of its high predictive validity. also supports the notion that CRF is a key neuropeptide coordinating behavioural and metabolic adaptation to stress (BOX 2). These data spurred almost all major pharmaceutical companies to discover and develop non-peptide CRFR1 antagonists.

CRFR1 antagonists. CRFR1 non-peptide antagonists bind to a transmembrane domain that changes the receptor conformation and prevents ligand binding. Most CRFR1 antagonists share a common pharmacophore, indicating that the receptor might have specific requirements for high-affinity interaction with a small chemical molecule. The first CRFR1 antagonist that entered clinical development was NBI 30775 (also known as R121919), which has a high affinity for CRFR1 $\left(K_{\mathrm{i}}=3.5 \mathrm{nM}\right)$, is highly selective, orally available and penetrates easily into the brain. This compound was first studied in 24 inpatients suffering from severe depression at the Max Planck Institute of Psychiatry in Munich ${ }^{55}$, and yielded promising results, but the compound was discontinued because of liver toxicity. However, subsequent controlled trials in patients with MDD or anxiety disorders using other CRFR1 antagonists (CP 316.311 (Pfizer); BMS-562086 (Bristol Myers Squibb); GSK561679 and GW-876008 (GlaxoSmithKline); ONO-2333Ms (Ono Pharmaceutical); and SSR125543 (Sanofi)) yielded negative results (TABLE 1).

These disappointing results emphasize a number of questions that already emerged after the failure of attempts to translate basic research findings with tachykinin receptors into clinical applications. To what degree can even the most compelling basic research findings for neuropeptide systems be extrapolated to the development of drugs that are clinically useful? On the one hand, there are no alternatives to cellular assays and animal models for probing novel chemical entities. On the other hand, it is not clear whether currently used chronic stress models or those that mimic early-life stress accurately reflect the biological situation in patients suffering from depression $^{56}$. It is known from clinical research that in a fraction of individuals (primarily those who are at risk), enduring stress can trigger the onset of depression ${ }^{57-59}$. A transgenic mouse that only overexpresses central CRF when stressed illustrates the need to use an animal model in which environmental and genetic factors are considered in combination ${ }^{60}$.

Other issues relate to the limitations of current behavioural screening models: in the forced swim test, mice that overexpress central CRF display prolonged struggling time that is shortened after the administration of a CRFR1 antagonist, which could be interpreted as a drug-evoked increase in depression-like behaviour ${ }^{61}$. This is another demonstration that an animal model that was originally developed to screen monoamine-based antidepressants is of limited value in the discovery of drugs that act on different neural mechanisms. Indeed, as the forced swim test does not have any construct validity regarding depression, its value in the discovery of novel mechanisms seems limited as this behaviour has nothing to do with the phenotype of depression in humans, and it is highly questionable whether reduced struggling time can be equated with behavioural despair (see REF. 56 for an in-depth review of animal models of neuropsychiatric disorders). In addition, the fact that these behavioural changes are observed after acute administration of antidepressant drugs, whereas in humans it takes weeks to months for these drugs to work, raises doubts about the utility of the test as a screen for novel drugs that are not based on monoamines.

One possible way to address such issues is to try and translate an objectifiable laboratory measure from the clinic into basic animal research. In many patients with 


\section{Box 2 | Support for the CRFR1 antagonist hypothesis in depression and anxiety}

\section{Clinical studies}

- Onset of depression is favoured by endured stress ${ }^{58,59}$

- Risk of depression in adulthood is enhanced by early-life trauma ${ }^{146-149}$

- Stress hormone regulation is defunct in many patients suffering from depression, as evidenced by elevation of stress hormone concentrations in the plasma and neuroendocrine hypothalamic-pituitary-adrenal (HPA) challenge tests ${ }^{150-152}$

- Post-mortem studies revealed elevated numbers of corticotropin-releasing factor (CRF)-expressing neurons in the hypothalamus, and decreased CRF binding ${ }^{98,153}$

- DNA sequence variations within the CRF-CRFR1 (CRF receptor 1 ) system contribute to the heritability of depression ${ }^{69,154}$

- DNA sequence variations in CRFR1 are associated with panic disorder - an effect that is enhanced by vasopressin $\mathrm{V}_{1 \mathrm{~B}}$ receptor polymorphisms ${ }^{67}$

- CRFR1 polymorphisms were shown to moderate the enhancement of depression in adulthood among individuals who suffered from trauma in early childhood ${ }^{72,73}$

- Polymorphisms in the gene encoding CRFR1 are associated with the response to antidepressant drugs ${ }^{68}$

Basic research studies

- Acute and chronic administration of CRF into the brain of experimental animals induces behavioural stress, including anxiety, sleep disturbance, loss of appetite and anhedonia ${ }^{155}$

- Early-life stress in rodents and monkeys induces elevations in CRF in the hippocampus and cerebrospinal fluid, and disrupts hippocampal CRFR1 expression, which accounts for long-lasting cognitive deficits ${ }^{156,157}$

- CRFR1-deficient mice are resilient to cognitive impairment induced by early-life stress, and conditional CRF overexpression mimics cognitive deficits induced by early-life trauma ${ }^{158}$

- Central CRF administration to neonatal rats replays the effects of early-life stress on cognition and brain morphology, which can be prevented by CRFR1 antagonists ${ }^{159,160}$

- Studies in transgenic mice in which the gene encoding CRFR1 is conditionally deleted in specific areas of the brain (including the prefrontal cortex) support the hypothesis that CRFR1 is involved in stress-elicited behavioural changes $^{161}$

- Transgenic mice conditionally overexpressing CRF express the behavioural repertoire that is characteristic for chronic stress; most of these symptoms disappear after CRFR1 antagonist administration ${ }^{61,162}$

- CRFR1 controls glutamatergic and dopaminergic systems, which have opposing effects on anxiety-like behaviour ${ }^{14}$

- CRFR1 antagonists suppress behavioural changes induced by chronic stress in rodents and monkeys ${ }^{163,164}$

- CRFR1 antagonists normalize rapid eye movement (REM) sleep disturbances in mice conditionally overexpressing $\mathrm{CRF}^{60}$

depression, the sleep electroencephalogram (EEG) is characterized by decreased slow-wave sleep and disinhibition of rapid eye movement (REM) sleep (which is characterized by random movements of the eyes, muscular atonia and frequently associated with dreaming ${ }^{62}$. Such phenomena were also observed in the sleep EEG of transgenic mice centrally overexpressing $\mathrm{CRF}^{60}$, which raises the question of whether central CRF overexpression is an important causal factor in patients with a specific signature in the sleep EEG. In line with this hypothesis, a CRFR1 antagonist was shown to suppress the enhanced disinhibition of REM in both CRFoverexpressing mice and in patients with depression ${ }^{63}$. Moreover, a correlation has been reported between the extent of REM disinhibition and clinical improvement with CRFR1 antagonist treatment, further supporting the idea that sleep EEG might be a biomarker for identifying potential responders to CRFR1 antagonists ${ }^{64}$.

The recruitment of patients with genetic variations that are indicative of excessive CRF signalling may also aid the future development of CRFR1 antagonists. Particular CRFR1 polymorphisms are associated with panic disorders ${ }^{65}$, and the effect is even stronger when they are combined with a single nucleotide polymorphism (SNP) in the gene encoding arginine vasopressin receptor $1 \mathrm{~B}(A V P R 1 B)$, supporting the notion that vasopressin and CRF are central to the development and course of stress-related disorders, including pathological anxiety ${ }^{66,67}$. A three-SNP haplotype with CRFR1 was first reported to be associated with an antidepressant response among patients with anxious depression ${ }^{68}$. This finding was replicated in a Chinese population ${ }^{69}$ and also in the STAR ${ }^{\star}$ D sample, in which an SNP in the CRFR1 promoter was found to predict beneficial response to the selective serotonin reuptake inhibitor citalopram ${ }^{70}$. Although a first re-sequencing effort of exonic regions in CRHR1 in a sample of Mexican Americans did not yield significant associations with response to antidepressant treatment ${ }^{71}$, it is foreseeable that only more rigid sequencing efforts in large samples will ultimately reveal the degree to which DNA variants in the CRHR1 gene contribute to inherited vulnerability.

Genetic factors could also be involved in increased susceptibility to depression and other stress-related disorders following stressful early-life experiences. For example, several reports support the possibility that SNPs 
in CRFR1 moderate the effects of early trauma on stressrelated disorders in adulthood ${ }^{72-74}$. A three-SNP CRFR1 haplotype has been described that was associated with less depressive symptoms than other CRFR1 haplotypes in adults who experienced abuse as children ${ }^{73}$, and this finding has been replicated and extended in other samples with various stress-related phenotypes ${ }^{74}$. Data from endocrine studies indicate that individuals who were exposed to early trauma and carry the high-risk CRFR1 haplotype display an increased responsivity of the HPA axis, even in the absence of a current psychiatric disorder. Conversely, traumatized carriers of the protective haplotypes do not display HPA axis hyperactivity ${ }^{75}$, suggesting that CRFR1 may moderate the long-term effects of early trauma and early-life events in general. Early-life stress can also modify gene expression by altering the methylation pattern at $\mathrm{CpG}$ islands ${ }^{76}$, and mice from a strain that is resilient to social stress indeed show decreased $\mathrm{Crh}$ gene promoter methylation and, consequently, elevated Crh mRNA expression ${ }^{77,78}$.

Brain penetrance and the receptor occupancy of small non-peptide CRFR1 antagonists is another issue that has yet to be resolved. A prevailing view in psychopharmacology is that a therapeutic dose range measured by plasma levels of a CNS drug can be established by positron emission tomography (PET), which allows assessment of receptor occupancy ${ }^{79}$. PET ligands for CRFR1 that are suitable for clinical applications would be an important tool for dose-finding studies. Unfortunately, despite considerable effort, no PET ligand has yet been developed that would help to resolve the question of whether sufficient amounts of an investigative CRFR1 antagonist have entered the brain ${ }^{80}$.

It may also be important to consider inter-individual differences in the passage of drugs across the bloodbrain barrier that are linked to variants in the gene encoding the transporter molecule ATP-binding cassette subfamily B member 1 (also known as P-glycoprotein) as well as the P-glycoprotein substrate characteristics of the drug ${ }^{81}$. An alternative possibility to assess brain penetrance and its functional consequences is to measure the effect of a central CRFR1 antagonist on psychosocial stress-elicited HPA activity ${ }^{82}$. After 10 days of treatment with NBI 34071 (GlaxoSmithKline/Neurocrine), healthy probands showed blunted HPA response to stress, indicating that the drug had an effect on the stress hormone axis. The possibility that this finding is secondary to CRFR1 antagonist-induced effects on pituitary corticotropic cells cannot be fully rejected but seems to be unlikely, as the HPA response to intravenous CRF was not affected in these probands, which is in line with the established abundance of pituitary CRFRs.

So far, the clinical efficacy of CRFR1 antagonists has been investigated in patients with MDD and anxiety disorders, and trials in other indications - including PTSD and irritable bowel disease - are currently underway. Common to all of these trials is that a very specific mechanism is probed in patient groups that are heterogeneous on all observation levels, ranging from the psychopathology to biomarkers and DNA sequence variations. Unsurprisingly, trials recruiting unspecified patient populations favour unspecific drugs. It is noteworthy that current comparator drugs have many other effects beyond modulating monoaminergic neurotransmission. Thus, future trials with CRFR1 antagonists are likely to be aided by the use of biomarkers and genetic tests to ensure that the study samples are enriched with patients in whom excessive CRF-CRFR1 signalling is one of the major pathogenetic factors.

\section{Vasopressin}

The nonapeptide vasopressin, which is synthesized in the paraventricular nucleus of the hypothalamus and the supraoptic nucleus, is well known for its role in hydromineral balance but there is also clear evidence that it has an important role as a regulator of pituitary ACTH secretion $^{83-85}$ and as a neuromodulator in the brain ${ }^{86}$. Vasopressin-containing neurons have been characterized in extrahypothalamic areas, such as the medial amygdala and the bed nucleus of the stria terminalis, which innervate limbic structures such as the lateral septum and the ventral hippocampus ${ }^{87-89}$ (FIG. 1C). The central actions of this neuropeptide are mediated by specific G proteincoupled receptors - that is, vasopressin $\mathrm{V}_{1 \mathrm{~A}}$ receptor $\left(\mathrm{V}_{1 \mathrm{~A}}\right)$ and $\mathrm{V}_{1 \mathrm{~B}}$ receptor ${ }^{90-92}$ — which are widely distributed in the CNS, including in the lateral septum, cortex and hippocampus, as well as the pituitary $\left(\mathrm{V}_{1 \mathrm{~B}}\right.$ receptor only) ${ }^{90,93-95}$ (FIG. 1C).

The neuroanatomical distribution of vasopressin pathways and its receptors has prompted speculation about the functional role of vasopressin in emotional processes and in the pathophysiology of affective disorders. The peptide is crucial for the adaptation of the HPA axis during stress, through its ability to potentiate the stimulatory effect of CRF. Exposure to stress stimulates the release of vasopressin from the median eminence into the pituitary portal circulation, and increases the expression of vasopressin in the paraventricular nucleus of the hypothalamus in rodents ${ }^{96}$. Studies in humans showed that the release of vasopressin was significantly correlated with anxiety symptoms in healthy volunteers after anxiogenic drug challenge ${ }^{97}$. Abnormalities in vasopressin levels or vasopressin receptor activity have been detected in patients with depression ${ }^{98-101}$ and obsessive-compulsive disorder ${ }^{102}$. Moreover, there is evidence suggesting that HPA axis dysregulation in depression may be associated with increased vasopressinergic control of the axis ${ }^{103,104}$. In this context, normalizing vasopressinergic activity via the blockade of the $\mathrm{V}_{1 \mathrm{~B}}$ receptor may be beneficial for the treatment of stress-related disorders, and this has driven the search for small-molecule vasopressin $\mathrm{V}_{1 \mathrm{~B}}$ receptor antagonists ${ }^{105}$.

The vasopressin system is further linked to mood disorders and psychiatric diseases by the findings that arginine vasopressin and CRF potentiate their actions at corticotropic cells ${ }^{106,107}$, that CRFR 1 and $V_{1 B}$ receptors can heterodimerize and that a major SNP haplotype of the $\mathrm{V}_{1 \mathrm{~B}}$ receptor influences resistance to depression. In many patients with depression, plasma ACTH and cortisol secretion is inadequately suppressed after the administration of a low dose of dexamethasone ${ }^{108}$. After intravenous CRF administration, patients who are pretreated with dexamethasone show an excessive HPA 


\section{Box 3 | Other neuropeptides that may be relevant in psychiatric diseases}

\section{Neuropeptide $Y$}

Neuropeptide Y (NPY) is a 36-amino-acid peptide of the pancreatic polypeptide (PP) family that includes PP and peptide YY. NPY and its receptors are widely distributed throughout the peripheral nervous system and the central nervous system (CNS). In the brain, significant levels of NPY are found in most regions, including the cerebral cortex, hippocampus, thalamus and brainstem. NPY exerts its action via at least four $\mathrm{G}_{\mathrm{i}}$ protein-coupled receptors: NPY receptor 1 (NPY1R), NPY2R, NPY4R and NPY5R. The role of NPY in mood disorders has been studied extensively, with a focus on NPY1R and NPY2R, which are believed to be implicated in anxiety and depression. However, only a few scattered efforts have focused on developing an NPY receptor modulator for psychiatric purposes; there is no compound currently in development ${ }^{165}$. The major challenge associated with NPY is in obtaining non-peptide brain-penetrant ligands.

\section{Nociceptin}

The heptadecapeptide nociceptin (also known as orphanin FQ) exhibits structural homology with the opioid peptides and binds to an opioid-like G protein-coupled receptor, opiate-receptor-like 1 (ORL1), but it does not bind to any of the previously identified opioid peptides or ligands, or to activated opioid receptors ${ }^{166}$. Nociceptin and its receptor are found in the CNS, with high levels in the cortex, olfactory nucleus, amygdala and hippocampal formation. Evidence from studies in animal models shows that nociceptin agonists could have utility in anxiety disorders, whereas antagonists may be useful for the treatment of major depressive disorder ${ }^{166}$. Several non-peptide ORL1 ligands have been identified but none has entered clinical development, and there are currently no further research efforts in this field. Nociceptin, because of its broad CNS distribution and many physiological roles, may be a risky target. For example, ORL1 agonists have been shown to produce amnestic effects at anxiolytic-like doses, which precludes their development as anxiolytic agents.

\section{Melanin-concentrating hormone}

Melanin-concentrating hormone $(\mathrm{MCH})$ is a 19 -amino-acid cyclic peptide that is predominantly expressed in the hypothalamus. It interacts with two G protein-coupled receptors: MCH receptor 1 (MCHR1) and MCHR2 (expressed only in humans). Expression of MCHR1 is seen throughout the brain, with highest levels in the cortex, hippocampus, amygdala and nucleus accumbens, suggesting a possible role of $\mathrm{MCH}$ in mood disorders and schizophrenia ${ }^{167,168}$. Mice in which the Mchr1 gene has been knocked out exhibit less anxiety-like behaviours than wild-type mice. Administration of MCHR1 antagonists has been shown to produce anxiolytic- and antidepressant-like effects. Finally, there is evidence that the MCH system may act as a regulator of sensorimotor gating, which is known to be deficient in patients with schizophrenia. Although several non-peptidic MCHR1 antagonists have been described, no such compound has yet reached a clinical phase for the treatment of a psychiatric disease. Perhaps the main challenges associated with $\mathrm{MCH}$ receptor ligands are the potential adverse effects of an MCHR1 antagonist, as this receptor is highly expressed in peripheral tissues such as adipose tissue, the intestines, lymphocytes and the pituitary.

\section{Galanin}

The neuropeptide galanin is a 29-amino-acid peptide with a carboxy-terminal amide. It has a widespread distribution in the CNS and the peripheral nervous system of many mammalian species, and exerts a diversity of biological effects. In the brain, it coexists with noradrenaline in the locus coeruleus neurons, and with 5-hydroxytryptamine (5-HT; also known as serotonin) in the dorsal raphe nucleus. The galanin receptor family currently comprises three members, galanin receptor 1 (GALR1), GALR2 and GALR3, which are all G protein-coupled receptors. The peptide and its receptors are found in limbic regions of the rat brain, including the amygdala, bed nucleus of the stria terminalis, hippocampus and hypothalamus. The available data from behavioural studies in animals suggest that targeting the galanin system might be of therapeutic benefit in anxiety and depressive disorders ${ }^{169,170}$. However, the search for specific and brain-penetrant galanin receptor agonists and/or antagonists that can pharmacologically discriminate between receptor subtypes remains a challenge.

\section{Oxytocin}

Oxytocin is a small 9-amino-acid peptide with one current known receptor, oxytocin receptor (OXTR), which is a seventransmembrane $\mathrm{G}$ protein-coupled receptor. Oxytocin is primarily synthesized in the magnocellular neurons of the paraventricular and supraoptic nuclei of the hypothalamus, which project to the posterior pituitary and a variety of regions of the brain, including the cortex and the limbic system. Many studies in humans have reported that oxytocin can modulate social relationships, suggesting a promising therapeutic potential of oxytocin in the treatment of psychiatric conditions associated with psychosocial problems, such as schizophrenia and autism spectrum disorder ${ }^{171}$.

\section{Neuropeptide S}

Neuropeptide S receptor (NPSR) and its endogenous ligand neuropeptide S constitute a signalling system with multiple functions including arousal, anxiety and memory. Neuropeptide $S$ administration reduces anxiety-like behaviour in several animal models via NPSR, a G protein-coupled receptor ${ }^{172}$. The mode of action, which is completely different from benzodiazepines, involves the internalization of the neuropeptide S-NPSR complex into neuronal cells ${ }^{173}$. To our knowledge, there are no known NPSR ligands available that could serve as drug candidates acting on this system; interestingly, however, the anxiolytic effects of neuropeptide $\mathrm{S}$ can be produced by intranasal administration ${ }^{173}$.

response. This is thought to be indicative of elevated levels of central vasopressin that is released in parallel with CRF to the pituitary, which helps to override the suppressive effect of dexamethasone. Many clinical studies assessing the response to antidepressant treatment in patients with depression now include a dexamethasoneCRF test to characterize their HPA status and for normalization of test results ${ }^{109-112}$.

The first non-peptidergic antagonist targeting the $\mathrm{V}_{1 \mathrm{~B}}$ receptor, SSR149415, was described in 2002 (REF. 113). 
In rodents, SSR149415 blocked several endocrine responses (that is, ACTH release), neurochemical responses (that is, noradrenaline release) and autonomic responses (that is, hyperthermia) following various stress exposures ${ }^{114}$. Moreover, the drug was able to attenuate some but not all stress-related behaviours in rodents ${ }^{114,115}$. Although the antidepressant-like activity of the compound was comparable to that of known antidepressants, the overall profile displayed in anxiety tests was different from that of benzodiazepines - the standard anxiolytics. Benzodiazepines produced robust effects in most anxiety tests, whereas SSR149415 showed clear effects only in particularly stressful situations. Since SSR149415 was described, there have been several preclinical reports of other selective nonpeptide $\mathrm{V}_{1 \mathrm{~B}}$ receptor antagonists (for example, Org 52186 (Organon) as well as ABT-436 and ABT-558 (Abbott)) that have confirmed the therapeutic value of this approach for treating affective disorders ${ }^{116,117}$ (FIG. 2).

Two efficacy and tolerability studies in MDD and one study in GAD were conducted using SSR149415 (TABLE 1). In all the trials, SSR149415 was safe and well tolerated, and had no negative effect on electrocardiogram (ECG) parameters or the HPA axis at the doses studied. However, the drug was discontinued as it failed to satisfy efficacy expectations. There is currently no other $\mathrm{V}_{1 \mathrm{~B}}$ receptor antagonist in advanced clinical development for stressrelated disorders. It is worth noting that SSR149415 was tested at doses (100 $\mathrm{mg}$ and $250 \mathrm{mg}$ ) that did not affect the ACTH response to a CRF challenge - a putative marker of drug activity. Doses higher than $250 \mathrm{mg}$ of SSR149415 have been found to significantly attenuate this response in a Phase I study (L. Arvanitis, personal communication). It is therefore possible that a dose of SSR149415 higher than $250 \mathrm{mg}$ might have produced more convincing effects, at least in patients with MDD. Finally, similarly to the situation with CRFR1 antagonists, blocking $\mathrm{V}_{1 \mathrm{~B}}$ receptors may only be beneficial in those patients in whom signalling between vasopressin and the $V_{1 B}$ receptor is enhanced. Further clinical development of $\mathrm{V}_{1 \mathrm{~B}}$ receptor antagonists will require genetic tests and biomarkers to identify patients who are potentially responsive to $\mathrm{V}_{1 \mathrm{~B}}$ receptor antagonists.

\section{Neurotensin}

In 1973, the tridecapeptide neurotensin was first isolated from the bovine hypothalamus ${ }^{118}$. It was found to have a broad spectrum of physiological activities: acting as a neurotransmitter in the brain; behaving as a digestive hormone in the gut; and acting as a regulator of cardiac output and blood pressure in the cardiovascular system $^{119}$. In the CNS, neurotensin is associated with several neurotransmitter systems, including dopaminergic, serotonergic, GABAergic, glutamatergic and cholinergic systems ${ }^{120-122}$.

The effects of neurotensin are mediated by two $G$ protein-coupled seven-transmembrane domain receptors (neurotensin receptor $1\left(\mathrm{NTR}_{1}\right)$ and $\left.\mathrm{NTR}_{2}\right)^{123,124}$, and a type I amino acid receptor ( $\mathrm{NTR}_{3}$; also known as sorti$\left.\operatorname{lin}^{125}\right)^{124}$. NTR 1 has attracted much attention as it has a major role in the modulation of neurotransmitter systems ${ }^{126}$. It is expressed in both neurons and glial cells, and is heterogeneously distributed throughout the CNS, with the highest levels of expression in the substantia nigra, ventral tegmental area, lateral septum, bed nucleus of the stria terminalis as well as the prefrontal, cingulate, insular and suprarhinal cortices ${ }^{127-130}$ (FIG. 1d). Considerable attention has focused on the role of neurotensin in regulating dopaminergic function, as central administration of the peptide has behavioural effects that closely resemble those elicited by antipsychotic drugs that regulate the mesocorticolimbic and neostriatal dopaminergic system $^{120-122}$. Dysfunction of neurotensin neurotransmission in this system has been hypothesized to be involved in the pathogenesis of schizophrenia, and this has led to the idea that neurotensin receptors, in particular $\mathrm{NTR}_{1}$, may represent novel targets for the treatment of psychoses.

To date, the only available $\mathrm{NTR}_{1}$ agonists are peptide analogues of neurotensin $\left(\mathrm{NT}_{8-13}\right)$ that have been modified to increase metabolic stability and CNS penetration ${ }^{131-135}$. As with centrally administered neurotensin, these agonists have similar behavioural and neurochemical effects to antipsychotics in animal models of schizophrenia, with the added benefits of not causing weight gain or catalepsy - adverse events that are associated with some of the currently used antipsychotics ${ }^{121}$. Paradoxically, there is some evidence that repeated administration of $\mathrm{NTR}_{1}$ antagonists may have antipsychotic-like effects, as suggested by the observation that prolonged $\mathrm{NTR}_{1}$ blockade produced an inhibition of firing rate in dopaminergic cells in the ventral tegmental area, similarly to haloperidol and clozapine, two pharmacologically different prototypical antipsychotics ${ }^{136}$. However, in a Phase IIa double-blind clinical trial the non-peptide $\mathrm{NTR}_{1}$ antagonist meclinertant (SR48692) was found to be inactive in the treatment of schizophrenia and schizoaffective disorder ${ }^{43}$ (TABLE 1). It is noteworthy that based on the hypothesis that neurotensin agonism has an antipsychotic effect, a worsening of psychosis might have been predicted in patients who received meclinertant compared with placebo, but this was not observed.

There is a lack of results from clinical trials with NTR $_{1}$ agonists in schizophrenia. To the best of our knowledge, the neurotensin analogue NT69L is the only NTR $_{1}$ agonist that has been evaluated in a Phase I trial ${ }^{137}$. The reports of this study were scarce but the drug produced some hypotension, which may have led to its discontinuation. Such an adverse effect may not be surprising as there has been some concern over the potential side effects of neurotensin receptor agonists owing to the large number of neurotensin receptors in the periphery that regulate blood pressure ${ }^{121}$. Another potential issue regarding the therapeutic efficacy of such drugs is the development of tolerance, which occurs rapidly (that is, after a single administration), as shown with NT69L in animal models of antipsychotic-like activity ${ }^{121}$.

Based on preclinical data, NTR 1 agonists have the potential to be an interesting option for the treatment of schizophrenia. However, the risk of producing side effects and the development of tolerance to the therapeutic effects, along with the difficulty in synthesizing non-peptide molecules that have favourable properties, has led to termination of the clinical development of $\mathrm{NTR}_{1}$ agonists. 
Table 2 | Pitfalls and proposed solutions for drug discovery targeting neuropeptide receptors

\begin{tabular}{|c|c|}
\hline Problems & What do we need? \\
\hline \multicolumn{2}{|l|}{ Target } \\
\hline $\begin{array}{l}\text { - No strong mechanistic hypothesis } \\
\text { supporting the involvement of } \\
\text { the neuropeptide system in the } \\
\text { psychiatric condition }\end{array}$ & $\begin{array}{l}\text { - Ensure that alteration in neuropeptide signalling is one of the major } \\
\text { pathogenetic factors (for example, CRF and vasopressin regulation is } \\
\text { defective in many patients suffering from depression, as evidenced } \\
\text { by the elevation of plasma stress hormone concentrations) } \\
\text { - Knowledge of DNA sequence variations (for example, within the } \\
\text { CRF-CRFR1 system they contribute to the heritability of depression) }\end{array}$ \\
\hline \multicolumn{2}{|l|}{ Drug } \\
\hline $\begin{array}{l}\text { - Limited knowledge on brain penetrance } \\
\text { and receptor occupancy } \\
\text { - Weak activity or differential pharmacology } \\
\text { at the human receptor }\end{array}$ & $\begin{array}{l}\text { - PET ligands to resolve the question of whether sufficient amounts } \\
\text { of the investigative drug have entered the brain } \\
\text { - Objectifiable laboratory tests (for example, psychosocial } \\
\text { stress-elicited HPA activity for CRFR1 antagonists) }\end{array}$ \\
\hline \multicolumn{2}{|l|}{ Animal models } \\
\hline $\begin{array}{l}\text { - Poor predictivity of the tests used, } \\
\text { which often relate to limited aspects } \\
\text { of the disease in 'normal' animals } \\
\text { - Screening tests validated by existing drugs } \\
\text { with a particular mechanism of action } \\
\text { may fail to identify compounds with novel } \\
\text { mechanisms of action } \\
\text { - Considerable emphasis on effects } \\
\text { following acute administration of the drug }\end{array}$ & $\begin{array}{l}\text { - Chronic models of the disease with face and construct validity } \\
\text { (for example, chronic mild stress for MDD) to adress several aspects } \\
\text { of the disease (for example, mouse defence test battery for anxiety } \\
\text { disorders) } \\
\text { - Animals that display innate features of the disease (for example, } \\
\text { BALB/c mice and HAB/LAB rats for anxiety, FSL rats for MDD) } \\
\text { - Transgenic animals that overexpress the neuropeptide and display } \\
\text { phenotypic features of the targeted disease (for example, mice } \\
\text { overexpressing CRF) }\end{array}$ \\
\hline \multicolumn{2}{|l|}{ Clinical trials } \\
\hline $\begin{array}{l}\text { - Specific mechanism is probed in patient } \\
\text { groups that are heterogeneous on } \\
\text { all observation levels, ranging from } \\
\text { psychopathology to biomarkers and DNA } \\
\text { sequence variations }\end{array}$ & $\begin{array}{l}\text { - Biomarkers and genetic tests to identify subgroups of patients in } \\
\text { whom a specific neuropeptidergic mechanism accounts for the } \\
\text { clinical condition (for example, individuals carrying the CRFR1 } \\
\text { haplotype) } \\
\text { - Biomarkers for responders (for example, sleep EEG to identify } \\
\text { individuals with MDD who are likely to respond to CRFR1 antagonists) }\end{array}$ \\
\hline
\end{tabular}

CRF, corticotropin-releasing factor; CRFR1, CRF receptor 1; EEG, electroencephalogram; FSL, Flinders sensitive line; HAB/LAB, rats selectively bred for high anxiety-related behaviour (HAB) or low anxiety-related behaviour (LAB); HPA, hypothalamic-pituitary-adrenal axis; MDD, major depressive disorder; PET, positron emission tomography.

\section{Conclusions and outlook}

Targeting neuropeptide receptors was strongly supported by basic neuroscience and led to major investments in drug discovery and development in this field. Various new non-peptide compounds emerged from these efforts but none of them has made it to the market, as clinical trials failed to demonstrate efficacy. Therefore, nearly all pharmaceutical companies have halted research and development in this area, and some have continued to pursue classical monoamine-based drugs. This conservative approach is risky, as the clinical effectiveness of such 'me too' drugs is only incremental compared with currently marketed agents, which will soon become much cheaper as they lose patent protection. As a result, many pharmaceutical companies are distancing themselves from psychopharmacology, despite the fact that psychiatric disorders are still the leading cause for health-care costs and only a fraction of patients are currently receiving treatment, which highlights the need for better drugs to serve a growing market ${ }^{138}$.

Although drugs targeting neuropeptide receptors have not met their expectations, we do not believe that the whole concept should be considered a failure. Furthermore, there are several other recently discovered neuropeptides not discussed in this article that may be relevant for the treatment of psychiatric diseases (BOX 3).
We suggest that the current status could be viewed as the end of the beginning for neuropeptide receptor drug discovery, and in TABLE 2 we summarize some of the key problems and potential solutions to advance the field further.

Among the most commonly noted reasons for the failure to successfully develop neuropeptide receptor ligands for MDD, anxiety disorders or schizophrenia is the poor predictivity of the animal models that have been used to screen these molecules. It is beyond the scope of this Review to address the issue of animal models of psychiatric diseases, which has been reviewed thoroughly in a recent article ${ }^{56}$, but it is noteworthy that in some instances what was considered to be compelling preclinical data did not translate into convincing clinical efficacy findings, thereby questioning the profiling strategies that were used for those drugs. Too often, strong conclusions on the potential of neuropeptide ligands in psychiatric disorders have been based on effects in a restricted number of models, which relate to only a few aspects of a psychiatric disease, and which were validated by established drugs with different mechanisms of action (for example, monoamine-based antidepressants or benzodiazepine anxiolytics). Clearly, drug selection based on data from animal models must be much more stringent and use a variety of models assessing different aspects of the disease. 
Another key issue that needs to be addressed is the study populations used in such trials. For example, a patient can fulfil the criteria for the DSM (Diagnostic and Statistical Manual) ${ }^{139}$ diagnosis of MDD by having any five out of nine listed symptoms, regardless of whether these symptoms include agitation, weight loss and insomnia, for example, or weight gain and hypersomnia as another example. In addition, some cardinal symptoms, such as so-called somatic symptoms, anxiety and panic or obsessive traits, may prevail without changes in diagnostic attribution. This clearly indicates that MDD is anything but a homogenous disease entity even on the level of psychopathology. This further warrants characterization of patients based on objectifiable measures such as those based on genetic tests and biomarkers $^{140}$.

Indeed, this heterogeneity may also be one reason for the limited magnitude of the effect of drugs that are currently used for the treatment of depression and schizophrenia, and has even led to the conclusion that antidepressants might not be effective at all ${ }^{141}$. By contrast, a recent review of meta-analyse ${ }^{142}$ concluded that drugs that are administered to patients with psychiatric diseases have a similar effect size to those used in general medicine. However, these studies were conducted mostly in outpatients who were not severely ill, which raises another question: are the patients who are recruited by clinical research organizations in outpatient settings for clinical trials representative of the patients who receive treatment as inpatients? Interestingly, this article found that effect sizes have decreased over recent decades, indicating either that drugs are less effective or that there is a bias in patient recruitment (that is, that fewer severely ill patients have been enrolled in such studies). In the absence of the use of objectifiable laboratory tests, this issue cannot be resolved.

The future development of drugs targeting neuropeptide receptors also has to take into consideration the specificity of their mechanism of action. Unlike biogenic amines, which are released from vesicles into synapses during high- and low-frequency activity, neuropeptides are preferentially released under bursts or high-frequency firing ${ }^{143}$. This, along with other differences in the synthesis, release, reuptake, binding affinities and degradation of neurotransmitters and neuropeptides, also needs to be considered ${ }^{144}$. Genetic tests and biomarkers are needed to identify subgroups of patients in whom a specific neuropeptidergic mechanism accounts for the clinical condition and who would thus be anticipated to benefit from a specific drug intervention.

It is important to note, however, that personalizing treatment requires not only determining, for example, whether a patient might respond preferably to $\mathrm{V}_{1 \mathrm{~B}}$ receptor antagonist, an NMDA ( $N$-methyl-D-aspartate) receptor antagonist or a selective serotonin reuptake inhibitor, but also finding the right drug combination for the right patient at the right time. For instance, the anxiety-like behaviour induced by CRF-CRFR1 signalling is conveyed via glutamatergic receptors, which means that in psychiatric disorders in which anxiety prevails, a combination of an NMDA receptor antagonist with a CRFR1 antagonist would be anticipated to benefit patients ${ }^{145}$. This further highlights the point that as long as we cannot stratify patients, the clinical potential of neuropeptide receptor antagonists may not be realized, and so advances in this area are crucial for the future of the field.
1. Kramer, M. S. et al. Distinct mechanism for antidepressant activity by blockade of central substance P receptors. Science 281, 1640-1645 (1998).

2. Belzung, C., Yalcin, I., Griebel, G., Surget, A. \& Leman, S. Neuropeptides in psychiatric diseases: an overview with a particular focus on depression and anxiety disorders. CNS Neurol. Disord. Drug Targets 5, 135-145 (2006).

3. Griebel, G. Is there a future for neuropeptide receptor ligands in the treatment of anxiety disorders? Pharmacol. Ther. 82, 1-61 (1999).

4. Steckler, T. Developing small molecule nonpeptidergic drugs for the treatment of anxiety disorders: is the challenge still ahead? Curr. Top. Behav. Neurosci. 2 415-428 (2010).

5. Herranz, R. Cholecystokinin antagonists: pharmacological and therapeutic potential. Med. Res. Rev. 23, 559-605 (2003).

6. Turiault, M., Cohen, C. \& Griebel, G. in Encyclopedia of Psychopharmacology (ed. Stolerman, I. P.) 1301-1303 (Springer-Verlag 2010).

7. Regoli, D., Boudon, A. \& Fauchere, J. L. Receptors and antagonists for substance $P$ and related peptides. Pharmacol. Rev. 46, 551-599 (1994).

8. Rigby, M., O'Donnell, R. \& Rupniak, N. M. Species differences in tachykinin receptor distribution: further evidence that the substance $\mathrm{P}\left(\mathrm{NK}_{1}\right)$ receptor predominates in human brain. J. Comp. Neurol. 490, 335-353 (2005)

9. Beaujouan, J. C., Torrens, Y., Saffroy, M., Kemel, M. L. $\&$ Glowinski, J. A 25 year adventure in the field of tachykinins. Peptides 25, 339-357 (2004).

10. Varty, G. B. et al. The gerbil elevated plus-maze II: anxiolytic-like effects of selective neurokinin NK 1 receptor antagonists. Neuropsychopharmacology 27, 371-379 (2002).
11. Varty, G. B., Morgan, C. A., Cohen-Williams, M. E., Coffin, V. L. \& Carey, G. J. The gerbil elevated plus-maze I: behavioral characterization and pharmacological validation. Neuropsychopharmacology 27, 357-370 (2002).

12. Marco, N. et al. Activation of dopaminergic and cholinergic neurotransmission by tachykinin $\mathrm{NK}_{3}$ receptor stimulation: an in vivo microdialysis approach in guinea pig. Neuropeptides 32, 481-488 (1998).

13. Snider, R. M. et al. A potent nonpeptide antagonist of the substance $\mathrm{P}\left(\mathrm{NK}_{1}\right)$ receptor. Science $\mathbf{2 5 1}$, 435-437 (1991).

14. Herpfer, I. \& Lieb, K. Substance P receptor antagonists in psychiatry: rationale for development and therapeutic potential. CNS Drugs 19, 275-293 (2005).

15. Ebner, K. \& Singewald, N. The role of substance $P$ in stress and anxiety responses. Amino Acids 31, 251-272 (2006).

16. Gobbi, G. \& Blier, P. Effect of neurokinin-1 receptor antagonists on serotoninergic, noradrenergic and hippocampal neurons: comparison with antidepressant drugs. Peptides 26, 1383-1393 (2005).

17. Kramer, M. S. et al. Demonstration of the efficacy and safety of a novel substance $\mathrm{P}\left(\mathrm{NK}_{1}\right)$ receptor antagonist in major depression. Neuropsychopharmacology 29, 385-392 (2004)

18. Chappell, P. Effect of CP-122,721, a selective NKreceptor antagonist, in patients with MDD. In: Proceedings of the 42nd Annual Meeting of the New Clinical Drug Evaluation Unit (Boca Raton, Florida, 2002).

19. Ratti, E. et al. Results from 2 randomized, doubleblind, placebo-controlled studies of the novel $\mathrm{NK}_{1}$ receptor antagonist casopitant in patients with majo depressive disorder. J. Clin. Psychopharmacol. 31, 727-733 (2011).
20. Keller, M. et al. Lack of efficacy of the substance $P$ (neurokinin 1 receptor) antagonist aprepitant in the treatment of major depressive disorder. Biol. Psychiatry 59, 216-223 (2006).

21. Liu, K. S. et al. Is bigger better for depression trials? J. Psychiatr. Res. 42, 622-630 (2008).

22. Ratti, E. et al. Results from 2 randomized, doubleblind, placebo-controlled studies of the novel NK1 receptor antagonist casopitant in patients with major depressive disorder. J. Clin. Psychopharmacol. 31, 727-733 (2011).

23. Liebowitz, M., Sheehan, D., Melia, L. A. \& Siffert, J. Safety and efficacy of AV608 in subjects with social anxiety disorder. In: Proceedings of the 47th Annual Meeting of the New Clinical Drug Evaluation Unit (Boca Raton, Florida, 2007).

24. Tauscher, J. et al. Development of the 2 nd generation neurokinin-1 receptor antagonist LY686017 for social anxiety disorder. Eur. Neuropsychopharmacol. 20, 80-87 (2010).

25. Mathew, S. J. et al. A selective neurokinin-1 receptor antagonist in chronic PTSD: a randomized, doubleblind, placebo-controlled, proof-of-concept trial. Eur. Neuropsychopharmacol. 21, 221-229 (2011)

26. Rupniak, N. M. \& Kramer, M. S. Discovery of the antidepressant and anti-emetic efficacy of substance $\mathrm{P}$ receptor (NK1) antagonists. Trends Pharmacol. Sci. 20, 485-490 (1999).

27. Ebner, K., Sartori, S. B. \& Singewald, N. Tachykinin receptors as therapeutic targets in stress-related disorders. Curr. Pharm. Des. 15, 1647-1674 (2009).

28. Pringle, A. et al. Short-term NK1 receptor antagonism and emotional processing in healthy volunteers Psychopharmacology (Berl.) 215, 239-246 (2011)

29. Chandra, P. et al. NK1 receptor antagonism and emotional processing in healthy volunteers. J. Psychopharmacol. 24, 481-487 (2010). 
30. McCabe, C., Cowen, P. J. \& Harmer, C. J. NK1 receptor antagonism and the neural processing of emotional information in healthy volunteers. Int. J. Neuropsychopharmacol. 12, 1261-1274 (2009).

31. Emonds-Alt, X et al. A potent and selective non-peptide antagonist of the neurokinin $\mathrm{A}\left(\mathrm{NK}_{2}\right)$ receptor. Life Sci. 50, PL101-PL106 (1992).

32. Steinberg, R. et al. Selective blockade of neurokinin-2 receptors produces antidepressant-like effects associated with reduced corticotropin-releasing factor function. J. Pharmacol. Exp. Ther. 299, 449-458 (2001).

33. Louis, C. et al. Additional evidence for anxiolyticand antidepressant-like activities of saredutant (SR48968), an antagonist at the neurokinin-2 receptor in various rodent-models. Pharmacol. Biochem. Behav. 89, 36-45 (2008).

34. Overstreet, D. H., Naimoli, V. M. \& Griebel, G. Saredutant, an NK2 receptor antagonist, has both antidepressant-like effects and synergizes with desipramine in an animal model of depression. Pharmacol. Biochem. Behav. 96, 206-210 (2010).

35. Griebel, G., Perrault, G. \& Soubrie, P. Effects of SR48968, a selective non-peptide NK2 receptor antagonist on emotional processes in rodents. Psychopharmacology 158, 241-251 (2001).

36. Emonds-Alt, X. et al. SR 142801, the first potent non-peptide antagonist of the tachykinin NK3 receptor. Life Sci. 56, L27-L32 (1995).

37. Dawson, L. A. \& Smith, P. W. Therapeutic utility of NK3 receptor antagonists for the treatment of schizophrenia. Curr. Pharm. Des. 16, 344-357 (2010).

38. Juhl, K. et al. Identification of a new series of non-peptidic $\mathrm{NK}_{3}$ receptor antagonists. Bioorg. Med. Chem. Lett. 21, 1498-1501 (2011).

39. Simonsen, K. B., Juhl, K., Steiniger-Brach, B. \& Nielsen, S. M. Novel $\mathrm{NK}_{3}$ receptor antagonists for the treatment of schizophrenia and other CNS indications. Curr. Opin. Drug Discov. Devel. 13 379-388 (2010).

40. Malherbe, P., Ballard, T. M. \& Ratni, H. Tachykinin neurokinin 3 receptor antagonists: a patent review (2005-2010). Expert. Opin. Ther. Pat. 21, 637-655 (2011).

41. Griebel, G. $\&$ Beeske, S. Is there still a future for neurokinin 3 receptor antagonists as potential drugs for the treatment of psychiatric diseases? Pharmacol. Ther. 133, 116-123 (2011).

42. Spooren, W., Riemer, C. \& Meltzer, H. NK receptor antagonists: the next generation of antipsychotics? Nature Rev. Drug Discov. 4, 967-975 (2005).

43. Meltzer, H. Y., Arvanitis, L., Bauer, D. \& Rein, W. Placebo-controlled evaluation of four novel compounds for the treatment of schizophrenia and schizoaffective disorder. Am. J. Psychiatry 161, 975-984 (2004)

44. Evangelista, S. Talnetant GlaxoSmithKline. Curr. Opin Investig. Drugs 6, 717-721 (2005)

45. Liem-Moolenaar, M. et al. Psychomotor and cognitive effects of a single oral dose of talnetant (SB223412) in healthy volunteers compared with placebo or haloperidol. J. Psychopharmacol. 24, 73-82 (2010).

46. Vale, W. W. Spiess, J, Rivier C. \& Rivier, J. Characterization of a 41 residue ovine hypothalamic peptide that stimulates the secretion of corticotropin and $\beta$-endorphin. Science 213, 1394-1397 (1981).

47. Hauger, R. L. et al. International Union of Pharmacology. XXXVI. Current status of the nomenclature for receptors for corticotropin-releasing factor and their ligands. Pharmacol. Rev. 55, 21-26 (2003).

48. Chalmers, D. T., Lovenberg, T. W. \& De Souza, E. B. Localization of novel corticotropin-releasing factor receptor (CRF2) mRNA expression to specific subcortical nuclei in rat brain: comparison with CRF1 receptor mRNA expression. J. Neurosci. 15, 6340-6350 (1995).

49. Gehlert, D. R. et al. Stress and central urocortin increase anxiety-like behavior in the social interaction test via the CRF1 receptor. Eur. J. Pharmacol. 509 145-153 (2005)

50. De Souza, E. B. Corticotropin-releasing factor receptors: physiology, pharmacology, biochemistry and role in central nervous system and immune disorders. Psychoneuroendocrinology 20, 789-819 (1995).

51. Reul, J. M. \& Holsboer, F. Corticotropin-releasing factor receptors 1 and 2 in anxiety and depression. Curr. Opin. Pharmacol. 2, 23-33 (2002).
52. Behan, D. P. et al. Neurobiology of corticotropin releasing factor (CRF) receptors and CRF-binding protein: implications for the treatment of CNS disorders. Mol. Psychiatr. 1, 265-277 (1996).

53. Hauger, R. L., Risbrough, V., Brauns, O. \& Dautzenberg, F. M. Corticotropin releasing factor (CRF) receptor signaling in the central nervous system: new molecular targets. CNS Neurol. Disord. Drug Targets 5, 453-479 (2006).

54. Refojo, D. et al. Corticotropin-releasing hormone activates ERK1/2 MAPK in specific brain areas. Proc. Natl Acad. Sci. USA 102, 6183-6188 (2005).

55. Zobel, A. W. et al. Effects of the high-affinity corticotropin-releasing hormone receptor antagonist R121919 in major depression: the first 20 patients treated. J. Psychiatr. Res. 34, 171-181 (2000)

56. Nestler, E. J. \& Hyman, S. E. Animal models of neuropsychiatric disorders. Nature Neurosci. 13 , 1161-1169 (2010)

57. Paykel, E. S. Contribution of life events to causation of psychiatric illness. Psychol. Med. 8, 245-253 (1978)

58. Kendler, K. S., Karkowski, L. M. \& Prescott, C. A Causal relationship between stressful life events and the onset of major depression. Am. J. Psychiatr. 156 , 837-841 (1999)

59. Hammen, C. Stress and depression. Annu. Rev. Clin. Psychol. 1, 293-319 (2005).

60. Kimura, M. et al. Conditional corticotropin-releasing hormone overexpression in the mouse forebrain enhances rapid eye movement sleep. Mol. Psychiatry 15, 154-165 (2010).

61. Lu, A. et al. Conditional CRH overexpressing mice: an animal model for stress-elicited pathologies and treatments that target the central CRH system. Mol. Psychiatry 13, 989 (2008)

62. Lauer, C. J., Schreiber, W., Holsboer, F. \& Krieg, J. C. In quest of identifying vulnerability markers for psychiatric disorders by all-night polysomnography. Arch. Gen. Psychiatry 52, 145-153 (1995).

63. Held, K. et al. Treatment with the CRH 1-receptor-antagonist R121919 improves sleepEEG in patients with depression. J. Psychiatr. Res. 38, 129-136 (2004).

64. Holsboer, F. \& Ising, M. Stress hormone regulation: biological role and translation into therapy. Annu. Rev. Psychol. 61, 81-109 (2010).

65. Keck, M. E. et al. Combined effects of exonic polymorphisms in CRHR1 and AVPR1B genes in a case/control study for panic disorder. Am. J. Med. Genet. B Neuropsychiatr. Genet. 147B, 1196-1204 (2008)

66. Landgraf, R. The involvement of the vasopressin system in stress-related disorders. CNS Neurol. Disord. Drug Targets 5, 167-179 (2006).

67. Keck, M. E. Corticotropin-releasing factor, vasopressin and receptor systems in depression and anxiety. Amino Acids 31, 241-250 (2006)

68. Licinio, J. et al. Association of a corticotropin-releasing hormone receptor 1 haplotype and antidepressant treatment response in Mexican-Americans. Mol. Psychiatry 9, 1075-1082 (2004).

69. Liu, Z. et al. Association of corticotropin-releasing hormone receptor 1 gene SNP and haplotype with major depression. Neurosci. Lett. 404, 358-362 (2006)

70. Binder, E. B. et al. Association of polymorphisms in genes regulating the corticotropin-releasing facto system with antidepressant treatment response. Arch. Gen. Psychiatry 67, 369-379 (2010).

71. Dong, C., Wong, M. L. \& Licinio, J. Sequence variations of $A B C B 1$, SLC6A2, SLC6A3, SLC6A4, CREB 1, CRHR 1 and NTRK2: association with major depression and antidepressant response in Mexican-Americans. Mol. Psychiatry 14, 1105-1118 (2009)

72. Bradley, R. G. et al. Influence of child abuse on adult depression: moderation by the corticotropin-releasing hormone receptor gene. Arch. Gen. Psychiatry 65, 190-200 (2008)

73. Polanczyk, G. et al. Protective effect of $C R H R 1$ gene variants on the development of adult depression following childhood maltreatment: replication and extension. Arch. Gen. Psychiatry 66, 978-985 (2009)

74. Grabe, H. J. et al. Childhood maltreatment, the corticotropin-releasing hormone receptor gene and adult depression in the general population. Am. J. Med. Genet. B Neuropsychiatr. Genet. 153B, 1483-1493 (2010).
75. Tyrka, A. R. et al. Interaction of childhood maltreatment with the corticotropin-releasing hormone receptor gene: effects on hypothalamic pituitary-adrenal axis reactivity. Biol. Psychiatry 66, 681-685 (2009)

76. Murgatroyd, C. et al. Dynamic DNA methylation programs persistent adverse effects of early-life stress Nature Neurosci. 12, 1559-1566 (2009)

77. Elliott, E., Ezra-Nevo, G., Regev, L., Neufeld-Cohen, A $\&$ Chen, A. Resilience to social stress coincides with functional DNA methylation of the $\mathrm{Crf}$ gene in adult mice. Nature Neurosci. 13, 1351-1353 (2010).

78. Spengler, D., Rupprecht, R., Van, L. P. \& Holsboer, F. Identification and characterization of a 3',5'-cyclic adenosine monophosphate-responsive element in the human corticotropin-releasing hormone gene promoter. Mol. Endocrinol. 6, 1931-1941 (1992).

79. Grunder, G., Hiemke, C., Paulzen, M., Veselinovic, T. $\&$ Vernaleken, I. Therapeutic plasma concentrations of antidepressants and antipsychotics: lessons from PET imaging. Pharmacopsychiatry 44, 236-248 (2011).

80. Sullivan, G. M. et al. PET Imaging of CRF1 with $\left[{ }^{11} \mathrm{C}\right]$ R121920 and [ $\left.{ }^{11} \mathrm{C}\right] \mathrm{DMP} 696$ : is the target of sufficient density? Nucl. Med. Biol. 34, 353-361 (2007).

81. Uhr, M. et al. Polymorphisms in the drug transporter gene $A B C B 1$ predict antidepressant treatment response in depression. Neuron 57, 203-209 (2008).

82. Ising, M. et al. High-affinity CRF1 receptor antagonist NBI-34041: preclinical and clinical data suggest safety and efficacy in attenuating elevated stress response. Neuropsychopharmacology 32 1941-1949 (2007).

83. McCann, S. M. \& Brobeck J. R. Evidence for a role of the supraopticohypophyseal system in the regulation of adrenocorticotropin secretion. Proc. Natl Acad. Sci. USA 87, 318-324 (1954).

84. Antoni, F. A. Vasopressinergic control of pituitary adrenocorticotropin secretion comes of age. Front. Neuroendocrinol. 14, 76-122 (1993).

85. Aguilera, G. Regulation of pituitary ACTH secretion during chronic stress. Front. Neuroendocrinol. 15, 321-350 (1994)

86. Engelmann, M., Wotjak, C. T., Neumann, I., Ludwig, M. $£$ Landgraf, R. Behavioral consequences of intracerebral vasopressin and oxytocin: focus on learning and memory. Neurosci. Biobehav. Rev. 20 341-358 (1996)

87. Caffé, A. R., van Leeuwen, F. W. ¿ Luiten, P. G. M. Vasopressin cells in the medial amygdala of the rat project to the lateral septum and ventral hippocampus. J. Comp. Neurol. 261, 237-252 (1987).

88 De Vries, G J \& Buijs, R. M. The origin of the vasopressinergic and oxytocinergic innervation of the rat brain with special reference to the lateral septum. Brain Res. 273, 307-317 (1983).

89. van Leeuwen, F. W. \& Caffé, A. R. Vasopressinimmunoreactive cell bodies in the bed nucleus of the stria terminalis of the rat. Cell Tissue Res. $\mathbf{2 8}$ 525-534 (1983)

90. Lolait, S. J. et al. Extrapituitary expression of the rat V1b vasopressin receptor gene. Proc. Natl Acad. Sci. USA 92, 6783-6787 (1995).

91. Young, L. J., Toloczko, D. \& Insel, T. R. Localization of vasopressin $\left(\mathrm{V}_{1 \mathrm{a}}\right)$ receptor binding and mRNA in the rhesus monkey brain. J. Neuroendocrinol. 11 291-297 (1999).

92. Vaccari, C Lolait, S J \& Ostrowski, N L. Comparative distribution of vasopressin $\mathrm{V} 1 \mathrm{~b}$ and oxytocin receptor messenger ribonucleic acids in brain. Endocrinology 139, 5015-5033 (1998).

93. Morel, A., O'Carroll, A. M., Brownstein, M. J. \& Lolait, S. J. Molecular cloning and expression of a rat $\mathrm{V} 1 \mathrm{a}$ arginine vasopressin receptor. Nature 356 , 523-526 (1992)

94. Tribollet, E., Raufaste, D., Maffrand, J. \& Serradeil-Le Gal, C. Binding of the non-peptide vasopressin V receptor antagonist SR-49059 in the rat brain an in vitro and in vivo autoradiographic study. Neuroendocrinology 69, 113-120 (1999).

95. Stemmelin, J., Lukovic, L., Salome, N. \& Griebel, G Evidence that the lateral septum is involved in the antidepressant-like effects of the vasopressin $\mathrm{V}_{1 \mathrm{~b}}$ receptor antagonist, SSR 149415. Neuropsychopharmacology 30, 35-42 (2005).

96. Aguilera, G. \& Rabadan-Diehl, C. Vasopressinergic regulation of the hypothalamic-pituitary-adrenal axis: implications for stress adaptation. Regul. Pept. 96, 23-29 (2000). 
97. Abelson, J. L., Le Mellédo, J. M. \& Bichet, D. G Dose response of arginine vasopressin to the CCK-B agonist pentagastrin. Neuropsychopharmacology 24, 161-169 (2001)

98. Purba, J. S., Hoogendijk, W. J. G., Hofman, M. A. \& Swaab, D. F. Increased number of vasopressin- and oxytocin-expressing neurons in the paraventricular nucleus of the hypothalamus in depression. Arch. Gen. Psychiatry 53, 137-143 (1996).

99. Zhou, J. N. et al. Alterations in arginine vasopressin neurons in the suprachiasmatic nucleus in depression. Arch. Gen. Psychiatry 58, 655-662 (2001).

100. van Londen, L. et al. Plasma levels of arginine vasopressin elevated in patients with major depression. Neuropsychopharmacology 17 284-292 (1997).

101. Gjerris, A., Hammer, M., Vendsborg, P., Christensen, N. J. \& Rafaelsen, O. J. Cerebrospinal fluid vasopressi - changes in depression. Br. J. Psychiatry 147 696-701 (1985)

102. Altemus, M. et al. Abnormalities in the regulation of vasopressin and corticotropin releasing factor secretion in obsessive-compulsive disorder. Arch. Gen. Psychiatry 49, 9-20 (1992).

103. Holsboer, F. \& Barden, N. Antidepressants and hypothalamic-pituitary-adrenocortical regulation. Endocrine Rev. 17, 187-205 (1996).

104. Dinan, T. G. et al. Desmopressin normalizes the blunted adrenocorticotropin response to corticotropin-releasing hormone in melancholic depression: evidence of enhanced vasopressinergic responsivity. J. Clin. Endocrinol. Metab. 84, 2238-2240 (1999).

105. Griebel, G. et al. Anxiolytic- and antidepressant-like effects of the non-peptide vasopressin $\mathrm{V}_{1}$ receptor antagonist, SSR149415, suggest an innovative approach for the treatment of stress-related disorders. Proc. Natl Acad. Sci. USA 99, 6370-6375 (2002).

106. Gillies, G. E., Linton, E. A. \& Lowry, P. J. Corticotropin releasing activity of the new $C R F$ is potentiated several times by vasopressin. Nature 299, 355-357 (1982).

107. von Bardeleben, U., Holsboer, F., Stalla, G. K. $\&$ Muller, O. A. Combined administration of human corticotropin-releasing factor and lysine vasopressin induces cortisol escape from dexamethasone suppression in healthy subjects. Life Sci. 37 , 1613-1618 (1985).

108. De Kloet, E. R., Joels, M. \& Holsboer, F. Stress and the brain: from adaptation to disease. Nature Rev. Neurosci. 6, 463-475 (2005).

109. Ising, M. et al. Combined dexamethasone/ corticotropin releasing hormone test predicts treatment response in major depression - a potential biomarker? Biol. Psychiatry 62, 47-54 (2007)

110. Schule, S. et al. Restriction of HIV-1 replication in monocytes is abolished by Vpx of SIVsmmPBj. PLOS ONE 4, e7098 (2009).

111. Hennings, J. M. et al. Clinical characteristics and treatment outcome in a representative sample of depressed inpatients - findings from the Munich Antidepressant Response Signature (MARS) project. J. Psychiatr. Res. 43, 215-229 (2009)

112. Paslakis, G. et al. Venlafaxine and mirtazapine treatment lowers serum concentrations of dehydroepiandrosterone-sulfate in depressed patients remitting during the course of treatment J. Psychiatr. Res. 44, 556-560 (2010)

113. Serradeil-Le Gal, C et al. Characterization of (2S,4R)-1-[5-chloro-1-[(2,4-dimethoxyphenyl)sulfonyl] 3-(2-methoxy-phenyl)-2-oxo-2,3-dihydro- $1 \mathrm{H}$-indol3-yl]-4-hydroxy- $N, N$-dimethyl-2-pyrrolidine carboxamide (SSR 149415), a selective and orally active vasopressin $\mathrm{V}_{\text {}}$ receptor antagonist. J. Pharmacol. Exp. Ther. 300, 1122-1130 (2002).

114. Griebel, G., Stemmelin, J., Serradeil-Le Gal, C. \& Soubriê, P. Non-peptide vasopressin $\mathrm{V} 1 \mathrm{~b}$ recepto antagonists as potential drugs for the treatment of stress-related disorders. Curr. Pharm. Des. 11 1549-1559 (2005)

115. Roper, J., O'Carroll, A. M., Young, W. \& Lolait, S. The vasopressin Avpr $1 \mathrm{~b}$ receptor: molecular and pharmacological studies. Stress 14, 98-115 (2011).

116. Craighead, M. et al. Characterization of a novel and selective $\mathrm{V}_{1 \mathrm{~B}}$ receptor antagonist. Prog. Brain Res. 170, 527-535 (2008).

117. Wernet, W. et al. In vitro characterization of the selective vasopressin $\mathrm{V} 1 \mathrm{~b}$ receptor antagonists ABT-436 and ABT-558. Program No. 560.16. 2008 Neuroscience Meeting Planner (Washington DC; Society for Neuroscience; 2008).
118. Carraway, R. \& Leeman, S. E. The isolation of a new hypotensive peptide, neurotensin, from bovine hypothalami. J. Biol. Chem. 248, 6854-6861 (1973).

119. St Pierre, S. et al. Neurotensin, a multi-action peptide hormone. Union Med. Can. 109, 1447-1455 (1980)

120. Caceda, R., Kinkead, B. \& Nemeroff, C. B. Neurotensin: role in psychiatric and neurological diseases. Peptides 27, 2385-2404 (2006).

121. Kinkead, B. \& Nemeroff, C. B. Novel treatments of schizophrenia: targeting the neurotensin system. CNS Neurol. Disord. Drug Targets 5, 205-218 (2006)

122. Boules, M., Shaw, A., Fredrickson, P. \& Richelson, E. Neurotensin agonists: potential in the treatment of schizophrenia. CNS Drugs 21, 13-23 (2007).

123. Tanaka, K., Masu, M. \& Nakanishi, S. Structure and functional expression of the cloned rat neurotensin receptor. Neuron 4, 847-854 (1990).

124. Chalon, P et al. Molecular cloning of a levocabastinesensitive neurotensin binding site. FEBS Lett. 386 91-94 (1996).

125. Mazella, J. et al. The 100-kDa neurotensin receptor is gp95/sortilin, a non-G-protein-coupled receptor. J. Biol. Chem. 273, 26273-26276 (1998).

126. Pettibone, D. J. et al. The effects of deleting the mouse neurotensin receptor NTR1 on central and peripheral responses to neurotensin. J. Pharmacol. Exp. Ther. 300, 305-313 (2002)

127. Boudin, H., Pelaprat, D., Rostene, W. \& Beaudet, A. Cellular distribution of neurotensin receptors in rat brain: immunohistochemical study using an antipeptide antibody against the cloned high affinity receptor. J. Comp. Neurol. 373, 76-89 (1996).

128. Elde, R., Schalling, M., Ceccatelli, S., Nakanishi, S. $\&$ Hokfelt, T. Localization of neuropeptide receptor mRNA in rat brain: initial observations using probes for neurotensin and substance $\mathrm{P}$ receptors. Neurosci. Lett. 120, 134-138 (1990).

129. Fassio, A. et al. Distribution of the neurotensin receptor NTS 1 in the rat CNS studied using an aminoterminal directed antibody. Neuropharmacology 39, 1430-1442 (2000)

130. Alexander, M. J. \& Leeman, S. E. Widespread expression in adult rat forebrain of mRNA encoding high-affinity neurotensin receptor. J. Comp. Neurol. 402, 475-500 (1998)

131. Boules, M. et al. Neurotensin analog selective for hypothermia over antinociception and exhibiting atypical neuroleptic-like properties. Brain Res. 919 1-11 (2001).

132. Tyler, B. M. et al. In vitro binding and CNS effects of novel neurotensin agonists that cross the blood-brain barrier. Neuropharmacology 38, 1027-1034 (1999).

133. Tyler-McMahon, B. M., Stewart, J. A., Farinas, F., McCormick, D. J. \& Richelson, E. Highly potent neurotensin analog that causes hypothermia and antinociception. Eur. J. Pharmacol. 390, 107-111 (2000)

134. Machida, R., Tokumura, T., Tsuchiya, Y., Sasaki, A. \& Abe, K. Pharmacokinetics of novel hexapeptides with neurotensin activity in rats. Biol. Pharm. Bull. 16, 43-47 (1993).

135. Tokumura, T. et al. Stability of a novel hexapeptide, (Me)Arg-Lys-Pro-Trp-tert-Leu-Leu-OEt, with neurotensin activity, in aqueous solution and in the solid state. Chem. Pharm. Bull. (Tokyo) 38, 3094-3098 (1990).

136. Michaud, J. C., Gueudet, C. \& Soubrie, P. Effects of neurotensin receptor antagonists on the firing rate of rat ventral pallidum neurons. Neuroreport 11 , 1437-1441 (2000).

137. Richelson, E. NT69L: a neurotensin receptor agonist for treatment of neuropsychiatric diseases. Neuropsychopharmacology 30, S50 (2005).

138. Smith, K. Trillion-dollar brain drain. Nature 478 , 15 (2011).

139. American Psychiatric Association. Diagnostic and Statistical Manual of Mental Disorders, Fourth Edition, Text Revision (DSM-IV-TR). (American Psychiatric Association, Washington DC, 2000)

140. Holsboer, F. How can we realize the promise of personalized antidepressant medicines? Nature Rev. Neurosci. 9, 638-646 (2008).

141. Kirsch, I. The Emperor's New Drugs: Exploring the Antidepressant Myth (Bodley Head, 2010).

142. Leucht, S., Heres, S. \& Davis, J. M. Considerations about the efficacy of psychopharmacological drugs. Nervenarzt 82, 1425-1430 (2011)

143. Hokfelt, T., Bartfai, T. \& Bloom, F. Neuropeptides: opportunities for drug discovery. Lancet Neurol. 2 463-472 (2003)
144. Hokfelt, T., Johansson, O., Ljungdahl, A., Lundberg, J. M. \& Schultzberg, M. Peptidergic neurones. Nature 284, 515-521 (1980).

145. Refojo, D. et al. Glutamatergic and dopaminergic neurons mediate anxiogenic and anxiolytic effects of CRHR1. Science 333, 1903-1907 (2011)

146. Edwards, T. C., Patrick, D. L. \& Topolski, T. D. Quality of life of adolescents with perceived disabilities. J. Pediatr. Psychol. 28, 233-241 (2003).

147. Heim, C., Newport, D. J., Mletzko, T., Miller, A. H. \& Nemeroff, C. B. The link between childhood trauma and depression: insights from HPA axis studies in humans. Psychoneuroendocrinology 33, 693-710 (2008).

148. McCauley, J. et al. Clinical characteristics of women with a history of childhood abuse: unhealed wounds. JAMA 277, 1362-1368 (1997)

149. Molnar, B. E., Buka, S. L. \& Kessler, R. C. Child sexual abuse and subsequent psychopathology: results from the National Comorbidity Survey. Am. J. Public Health 91, 753-760 (2001).

150. Holsboer, F. The corticosteroid receptor hypothesis of depression. Neuropsychopharmacology 23 477-501 (2000)

151. Ising, M. et al. The combined dexamethasone/CRH test as a potential surrogate marker in depression. Prog. Neuropsychopharmacol. Biol. Psychiatry 29, 1085-1093 (2005).

152. Raison, C. L. \& Miller, A. H. When not enough is too much: the role of insufficient glucocorticoid signaling in the pathophysiology of stress-related disorders. Am. J. Psychiatry 160, 1554-1565 (2003)

153. Nemeroff, C. B. The role of corticotropin-releasing factor in the pathogenesis of major depression. Pharmacopsychiatry 21, 76-82 (1988).

154. Papiol, S. et al. Genetic variability at HPA axis in major depression and clinical response to antidepressant treatment. J. Affect. Disord. 104 83-90 (2007)

155. Holsboer, F. The rationale for corticotropin-releasing hormone receptor (CRH-R) antagonists to treat depression and anxiety. J. Psychiatr. Res. 33, 181-214 (1999)

156. Chen, Y. et al. Correlated memory defects and hippocampal dendritic spine loss after acute stress involve corticotropin-releasing hormone signaling. Proc. Natl Acad. Sci. USA 107, 13123-13128 (2010).

157. Coplan, J. D. et al. Persistent elevations of cerebrospinal fluid concentrations of corticotropinreleasing factor in adult nonhuman primates exposed to early-life stressors: implications for the pathophysiology of mood and anxiety disorders. Proc. Natl Acad. Sci. USA 93, 1619-1623 (1996).

158. Wang, X. D. et al. Forebrain CRF modulates early-life stress-programmed cognitive deficits. J. Neurosci. 31 13625-13634 (2011).

159. Brunson, K. L., Eghbal-Ahmadi, M., Bender, R. Chen, Y. \& Baram, T. Z. Long-term, progressive hippocampal cell loss and dysfunction induced by early-life administration of corticotropin-releasing hormone reproduce the effects of early-life stress. Proc. Natl Acad. Sci. USA 98, 8856-8861 (2001).

160. Ivy, A. S. et al. Hippocampal dysfunction and cognitive impairments provoked by chronic early-life stress involve excessive activation of $\mathrm{CRH}$ receptors. J. Neurosci. 30, 13005-13015 (2010).

161. Muller, M. B. et al. Limbic corticotropin-releasing hormone receptor 1 mediates anxiety-related behavior and hormonal adaptation to stress. Nature Neurosci. 6, 1100-1107 (2003).

162. Kolber, B. J. et al. Transient early-life forebrain corticotropin-releasing hormone elevation causes long-lasting anxiogenic and despair-like changes in mice. J. Neurosci. 30, 2571-2581 (2010).

163. Griebel, G., Perrault, G. \& Sanger, D. J. Characterization of the behavioral profile of the non peptide CRF receptor antagonist CP-154,526 in anxiety models in rodents. Comparison with diazepam and buspirone. Psychopharmacology 138, 55-66 (1998).

164. Habib, K. E. et al. Oral administration of a corticotropin-releasing hormone receptor antagonist significantly attenuates behavioral, neuroendocrine, and autonomic responses to stress in primates Proc. Natl Acad. Sci. USA 97, 6079-6084 (2000).

165. Brothers, S. P. \& Wahlestedt, C. Therapeutic potential of neuropeptide Y (NPY) receptor ligands. EMBO Mol. Med. 2, 429-439 (2010)

166. Civelli, O. The orphanin FQ/nociceptin (OFQ/N) system. Results Probl. Cell Differ. 46, 1-25 (2008) 
167. Shimazaki, T., Yoshimizu, T. \& Chaki, S. Melaninconcentrating hormone $\mathrm{MCH}_{1}$ receptor antagonists: a potential new approach to the treatment of depression and anxiety disorders. CNS Drugs $\mathbf{2 0}$ 801-811 (2006).

168. Chung, S. et al. The melanin-concentrating hormone (MCH) system modulates behaviors associated with psychiatric disorders. PLOS. ONE 6, e19286 (2011).

169. Holmes, A., Heilig, M., Rupniak, N. M., Steckler, T. $\&$ Griebel, G. Neuropeptide systems as novel therapeutic targets for depression and anxiety disorders. Trends Pharmacol. Sci. 24, 580-588 (2003).

170. Lang, R., Gundlach, A. L. \& Kofler, B. The galanin peptide family: receptor pharmacology, pleiotropic biological actions, and implications in health and disease. Pharmacol. Ther. 115, 177-207 (2007).

171. Striepens, N., Kendrick, K. M., Maier, W. \& Hurlemann, R. Prosocial effects of oxytocin and clinical evidence for its therapeutic potential. Front. Neuroendocrinol. 32, 426-450 (2011).

172. Xu, Y. L. et al. Neuropeptide S: a neuropeptide promoting arousal and anxiolytic-like effects. Neuron 43, 487-497 (2004).
173. Ionescu, I. et al. Intranasally administered neuropeptide S (NPS) exerts anxiolytic effects following internalization into NPS receptor-expressing neurons. Neuropsychopharmacology 37, 1323-1337 (2012).

174. Binneman, B. et al. A 6-week randomized, placebocontrolled trial of CP-316,311 (a selective CRH1 antagonist) in the treatment of major depression. Am. J. Psychiatry 165, 617-620 (2008)

175. Kirchhoff, V. D., Nguyen, H. T., Soczynska, J. K., Woldeyohannes, H. \& McIntyre, R. S. Discontinued psychiatric drugs in 2008. Expert. Opin. Investig. Drugs 18, 1431-1443 (2009).

176. Coric, V. et al. Multicenter, randomized, double-blind, active comparator and placebo-controlled trial of a corticotropin-releasing factor receptor-1 antagonist in generalized anxiety disorder. Depress. Anxiety 27. 417-425 (2010).

177. Griebel, G., Stahl, S. \& Arvanitis, L. The $V_{1 b}$ receptor antagonist SSR 149415 in the treatment of major depressive and generalized anxiety disorders: results from three double-blind, placebo-controlled studies. Neuropsychopharmacology 36, S351 (2011).

178. Furmark, T. et al. Cerebral blood flow changes after treatment of social phobia with the neurokinin-1 antagonist GR205171, citalopram, or placebo. Biol. Psychiatry 58, 132-142 (2005).
179. Kronenberg G et al. Randomized, double-blind study of SR142801 (osanetant). A novel neurokinin-3 (NK3) receptor antagonist in panic disorder with pre- and posttreatment cholecystokinin tetrapeptide (CCK-4) challenges. Pharmacopsychiatry 38, 24-29 (2005).

Acknowledgements

We thank S. Beeské and H. Junkert for their editorial assistance.

Competing interests statement

The authors declare competing financial interests: see Web version for details.

\section{FURTHER INFORMATION}

ClinicalTrials.gov website: http://clinicaltrials.gov

GSK Clinical Study Register:

http://www.gsk-clinicalstudyregister.com

Sanofi website - 28 April 2011 press release: http://en.

sanofi.com/Images/28323 20110428 Q12011 en.pdf

SUPPLEMENTARY INFORMATION

See online article: $\underline{\mathrm{S}}$ (table)

ALL LINKS ARE ACTIVE IN THE ONLINE PDF 
Table 1 I Drugs in clinical development for the treatment of schizophrenia, anxiety and major depressive disorders as of November 2011

\begin{tabular}{|c|c|c|c|c|}
\hline Drug & Company & $\begin{array}{c}\begin{array}{c}\text { Mechanism of } \\
\text { action }\end{array} \\
\end{array}$ & Indications & Status \\
\hline $\begin{array}{l}\text { Cariprazine (RGH- } \\
188)\end{array}$ & $\begin{array}{l}\text { Gedeon Richter - } \\
\text { Forest - } \\
\text { Mitsubishi Tanabe }\end{array}$ & $\mathrm{D}_{2 / 3}$ antagonist & Schizophrenia & III \\
\hline $\begin{array}{c}\text { Cariprazine (RGH- } \\
188)\end{array}$ & $\begin{array}{l}\text { Gedeon Richter - } \\
\text { Forest - } \\
\text { Mitsubishi }\end{array}$ & $\mathrm{D}_{2 / 3}$ antagonist & Depression & III \\
\hline $\begin{array}{l}\text { CYP-1020 (BL- } \\
1020)\end{array}$ & $\begin{array}{l}\text { BioLineRx - } \\
\text { Royalty Pharma }\end{array}$ & GABA enhancer & Schizophrenia & III \\
\hline $\begin{array}{l}\text { Edivoxetine (LY- } \\
\text { 2216684) }\end{array}$ & Lilly & $\begin{array}{l}\text { Norepinephrine } \\
\text { reuptake inhibitor }\end{array}$ & Depression & III \\
\hline $\begin{array}{l}\text { Levomilnacipran (F- } \\
\text { 2695) }\end{array}$ & $\begin{array}{l}\text { Pierre Fabre - } \\
\text { Forest } \\
\text { Laboratories }\end{array}$ & SNRI & Depression & III \\
\hline LU-AA-21004 & $\begin{array}{l}\text { Lundbeck - } \\
\text { Takeda }\end{array}$ & $\begin{array}{l}\text { 5- } \mathrm{HT}_{3} \text { antagonist, 5- } \\
\mathrm{HT}_{1 \mathrm{~A}} \text { agonist and 5- } \\
\mathrm{HT} \text { enhancer }\end{array}$ & $\begin{array}{l}\text { Anxiety and } \\
\text { Depression }\end{array}$ & III \\
\hline $\begin{array}{l}\text { Lurasidone (SM- } \\
\text { 13496) }\end{array}$ & $\begin{array}{l}\text { Dainippon - } \\
\text { Sumitomo } \\
\end{array}$ & $\begin{array}{l}\mathrm{D}_{2}, 5-\mathrm{HT}_{2 / 7} \\
\text { antagonist }\end{array}$ & Depression & III \\
\hline $\begin{array}{l}\text { Mifepristone (C- } \\
1073)\end{array}$ & $\begin{array}{l}\text { Corcept } \\
\text { Therapeutics }\end{array}$ & $\begin{array}{l}\text { Progesterone and } \\
\text { glucocorticoid } \\
\text { antagonist }\end{array}$ & Depression & III \\
\hline OPC-34712 & $\begin{array}{l}\text { Otsuka } \\
\text { Pharmaceuticals }\end{array}$ & $\begin{array}{l}\mathrm{D}_{2} \text { agonist, 5-HT } \\
\text { modulator }\end{array}$ & $\begin{array}{l}\text { Depression, } \\
\text { Schizophrenia }\end{array}$ & III \\
\hline $\begin{array}{l}\text { Paliflutine (RG- } \\
\text { 1678) }\end{array}$ & Roche & GlyT $_{1}$ inhibitor & Schizophrenia & III \\
\hline $\begin{array}{l}\text { Pomaglumetad (LY- } \\
\text { 2140023) }\end{array}$ & Lilly & mGluR $_{2 / 3}$ agonist & Schizophrenia & III \\
\hline $\begin{array}{l}\text { Tasimelteon (VEC- } \\
\text { 162) }\end{array}$ & $\begin{array}{l}\text { Vanda } \\
\text { Pharmaceuticals }\end{array}$ & Melatonin agonist & Depression & III \\
\hline TC-5214 & Targacept & $\begin{array}{l}\alpha_{4} \beta_{2} \text { nicotinic } \\
\text { antagonist }\end{array}$ & Depression & III \\
\hline $\begin{array}{l}\text { Zicronapine (LU- } \\
\text { 31130) }\end{array}$ & Lundbeck & $\begin{array}{l}\mathrm{D}_{1 / 2} \text { and } 5 \mathrm{HT}_{2 \mathrm{~A}} \\
\text { antagonist }\end{array}$ & Schizophrenia & III \\
\hline ABT-126 & Abbott & $\alpha_{7}$ nicotinic agonist & Schizophrenia & II \\
\hline ABT-288 & Abbott & $\mathrm{H}_{3}$ antagonist & Schizophrenia & II \\
\hline ADV-P8 & Advancell & Unspecified & Depression & II \\
\hline ADX-71149 & $\begin{array}{l}\text { Addex - } \\
\text { OrthoMcNeil }\end{array}$ & mGluR $_{2}$ PAM & Schizophrenia & II \\
\hline $\begin{array}{l}\text { ADX-71149 (JNJ- } \\
40411813)\end{array}$ & $\begin{array}{l}\text { Addex } \\
\text { Pharmaceuticals - } \\
\text { J\&J }\end{array}$ & mGluR $_{2}$ PAM & Schizophrenia & II \\
\hline AQW-051 & Novartis & Unspecified & Schizophrenia & II \\
\hline ARA-290 & $\begin{array}{l}\text { Araim } \\
\text { Pharmaceuticals }\end{array}$ & $\begin{array}{l}\text { Amino acid } \\
\text { pyroglutamate helix } \\
\text { B surface peptide }\end{array}$ & Depression & II \\
\hline
\end{tabular}




\begin{tabular}{|c|c|c|c|c|}
\hline AVN-101 & $\begin{array}{l}\text { Avineuro } \\
\text { Pharmaceuticals }\end{array}$ & 5- $\mathrm{HT}_{6}$ antagonist & $\begin{array}{l}\text { Anxiety, } \\
\text { Depression }\end{array}$ & II \\
\hline AVN-211 & $\begin{array}{l}\text { Avineuro } \\
\text { Pharmaceuticals }\end{array}$ & 5- $\mathrm{HT}_{6}$ antagonist & Schizophrenia & II \\
\hline AVN-397 & $\begin{array}{l}\text { Avineuro } \\
\text { Pharmaceuticals }\end{array}$ & 5- $\mathrm{HT}_{6}$ antagonist & Anxiety & II \\
\hline AZD-6765 & Astra Zeneca & NMDA antagonist & Depression & II \\
\hline BTG-1640 & BTG & Undisclosed & Anxiety & II \\
\hline CLR-3001 & Clera & Undisclosed & Depression & II \\
\hline $\begin{array}{l}\text { Coluracetam (BCI- } \\
540)\end{array}$ & BrainCells & $\begin{array}{l}\text { Neuron growth } \\
\text { promotor }\end{array}$ & Depression & II \\
\hline $\begin{array}{l}\text { Davenutide (AL- } \\
108)\end{array}$ & $\begin{array}{l}\text { Allon } \\
\text { Therapeutics }\end{array}$ & $\begin{array}{l}\text { Microtubule- } \\
\text { associated protein } \\
\text { modulator }\end{array}$ & Schizophrenia & II \\
\hline $\begin{array}{l}\text { Dipraglurant (ADX- } \\
48621)\end{array}$ & Addex & $\begin{array}{l}\text { mGluR5 negative } \\
\text { allosteric modulator }\end{array}$ & $\begin{array}{l}\text { Anxiety, } \\
\text { Depression }\end{array}$ & II \\
\hline ETS-6103 & $\begin{array}{l}\text { e-Therapeutics - } \\
\text { KLabs }\end{array}$ & Undisclosed & Depression & II \\
\hline EVP-6124 & EnVivo - Bayer & $\alpha_{7}$ nicotinic agonist & Schizophrenia & II \\
\hline Glyx-13 & Naurex & NMDA antagonist & Depression & II \\
\hline GSK-239512 & GSK & $\mathrm{H}_{3}$ antagonist & Schizophrenia & II \\
\hline ITI-007 & BMS & $\begin{array}{l}5 \mathrm{HT}_{2 \mathrm{~A}} \text { antagonist, } \mathrm{D}_{2} \\
\text { partial agonist, } 5-\mathrm{HT} \\
\text { reuptake transporter } \\
\text { modulator }\end{array}$ & Schizophrenia & II \\
\hline JNJ-26489112 & $\mathrm{J} \& \mathrm{~J}$ & Undisclosed & Depression & II \\
\hline $\begin{array}{l}\text { Ladostigil tartrate } \\
\text { (TV-3326) }\end{array}$ & Yissum & $\begin{array}{l}\text { Acetylcholinesterase } \\
\text { and MAO inhibitor }\end{array}$ & Depression & II \\
\hline Lisdexamfetamine & $\begin{array}{l}\text { Shire } \\
\text { Pharmaceuticals }\end{array}$ & $\begin{array}{l}\text { Adrenoreceptor } \\
\text { agonist }\end{array}$ & $\begin{array}{l}\text { Depression, } \\
\text { Schizophrenia }\end{array}$ & II \\
\hline $\begin{array}{l}\text { Losmapimod } \\
(856553)\end{array}$ & GSK & $\begin{array}{l}\text { p38 MAP kinase } \\
\text { inhibitor }\end{array}$ & Depression & II \\
\hline MP-01 & $\begin{array}{l}\text { MarcoPolo } \\
\text { Pharmaceuticals }\end{array}$ & 5- $\mathrm{HT}_{6}$ antagonist & Schizophrenia & II \\
\hline MT210 (CYR-101) & $\begin{array}{l}\text { Mitsubishi Tanabe } \\
\text { Pharma }\end{array}$ & $5 \mathrm{HT}_{2 \mathrm{~A}} / \sigma_{2}$ antagonist & Schizophrenia & II \\
\hline ORM-12741 & Orion Pharma & $\begin{array}{l}\alpha_{2 c} \text { adrenergic } \\
\text { agonist }\end{array}$ & Schizophrenia & II \\
\hline Orvepitant & GSK & $\mathrm{NK}_{1}$ antagonist & $\begin{array}{l}\text { Anxiety, } \\
\text { Depression } \\
\end{array}$ & II \\
\hline PF-2545920 & Pfizer & $\mathrm{PDE}_{10 \mathrm{~A}}$ inhibitor & Schizophrenia & II \\
\hline PH-94B & Pherin & Vomeropherin & Anxiety & II \\
\hline $\begin{array}{l}\text { Pivagabine (CXB- } \\
722 \text { ) }\end{array}$ & $\begin{array}{l}\text { CeNeRx } \\
\text { BioPharma }\end{array}$ & HPA axis modulator & $\begin{array}{l}\text { Anxiety, } \\
\text { Depression }\end{array}$ & II \\
\hline $\begin{array}{l}\text { RO4917523 (RG- } \\
7090)\end{array}$ & Roche & $\mathrm{mGluR}_{5}$ antagonist & Depression & II \\
\hline $\begin{array}{l}\text { Serdaxin }^{\mathrm{TM}}(\mathrm{RX}- \\
10100 \mathrm{XR})\end{array}$ & $\begin{array}{l}\text { Rexahn } \\
\text { Pharmaceuticals }\end{array}$ & $\mathrm{PDE}_{5}$ inhibitor & Depression & II \\
\hline $\begin{array}{l}\text { Talampanel (LY- } \\
\text { 300164) }\end{array}$ & Eli Lilly & $\begin{array}{l}\text { Non-competitive } \\
\text { AMPA antagonist }\end{array}$ & Anxiety & II \\
\hline TC-5619 & Targacept & $\alpha_{7}$ nicotinic agonist & Schizophrenia & II \\
\hline $\begin{array}{l}\text { Terdadioxetine (LU- } \\
\text { AA-24530) }\end{array}$ & $\begin{array}{l}\text { Lundbeck - } \\
\text { Takeda }\end{array}$ & $\begin{array}{l}\text { Monoamine } \\
\text { enhancer and 5- }\end{array}$ & Depression & II \\
\hline
\end{tabular}




\begin{tabular}{|c|c|c|c|c|}
\hline & & $\mathrm{HT}_{2 \mathrm{C} / 3}$ antagonist & & \\
\hline TGFK-08AA & Fabre Kramer & $\begin{array}{l}\text { 5-HT } 1 \mathrm{~A} \text { partial } \\
\text { agonist }\end{array}$ & Anxiety & II \\
\hline $\begin{array}{c}\text { TriRIMA }^{\mathrm{TM}}(\mathrm{CX}- \\
157) \\
\end{array}$ & $\mathrm{CeNeRx}$ & MAO inhibitor & $\begin{array}{l}\text { Anxiety and } \\
\text { Depression }\end{array}$ & II \\
\hline $\begin{array}{l}\text { Verucerfont } \\
\text { (GSK561679) }\end{array}$ & GSK & $\mathrm{CRF}_{1}$ antagonist & $\begin{array}{l}\text { Anxiety, } \\
\text { Depression }\end{array}$ & II \\
\hline ABIO-09/01 & Abiogen & Undisclosed & Depression & $\mathrm{I}$ \\
\hline ABT-436 & Abbott & V1b antagonist & Depression & $\mathrm{I}$ \\
\hline ABT-560 & NeuroSearch & $\alpha_{4} \beta_{2}$ nicotinic agonist & Schizophrenia & $\mathrm{I}$ \\
\hline AM-831 & Acadia & $\begin{array}{l}\mathrm{M}_{1} / \mathrm{D}_{2} / 5-\mathrm{HT}_{2 \mathrm{~A}} \\
\text { antagonist }\end{array}$ & Schizophrenia & $\mathrm{I}$ \\
\hline AMG-747 & Amgen & GlyT $_{1}$ inhibitor & Schizophrenia & I \\
\hline AZD-4451 & AstraZeneca & Undisclosed & $\begin{array}{l}\text { Bipolar } \\
\text { depression }\end{array}$ & I \\
\hline BCI-838 & Taiso & mGlur $_{2 / 3}$ antagonist & Depression & I \\
\hline BMS-866949 & BMS & $\begin{array}{l}\text { Triple reuptake } \\
\text { inhibitor }\end{array}$ & Depression & I \\
\hline BNC-210 & Bionomics & GABA $_{\mathrm{A}}$ modulator & Anxiety & $\mathrm{I}$ \\
\hline DSP-1053 & $\begin{array}{l}\text { Dainippon - } \\
\text { Sumitomo }\end{array}$ & $\begin{array}{l}5-\mathrm{HT}_{1 \mathrm{~A}} \text { antagonist, } \\
\text { SSRI }\end{array}$ & Depression & $\mathrm{I}$ \\
\hline EVT-103 & Evotec - Roche & NMDA antagonist & Depression & $\mathrm{I}$ \\
\hline GSK-1034702 & GSK & M1 agonist & Schizophrenia & I \\
\hline GSK-1144814 & GSK & $\mathrm{NK}_{1} / \mathrm{NK}_{3}$ antagonist & $\begin{array}{l}\text { Depression, } \\
\text { Schizophrenia }\end{array}$ & $\mathrm{I}$ \\
\hline GSK-356278 & GSK & PDE4 inhibitor & Depression & $\mathrm{I}$ \\
\hline $\begin{array}{l}\text { Irdabisant (CEP- } \\
\text { 26401) }\end{array}$ & Cephalon (Teva) & $\mathrm{H}_{3}$ antagonist & Schizophrenia & I \\
\hline JNJ-39393406 & $\mathrm{J} \& \mathrm{~J}$ & Unspecified & Schizophrenia & I \\
\hline LY-2940094 & Eli Lilly & $\begin{array}{l}\text { Nociceptin } \\
\text { antagonist }\end{array}$ & Depression & $\mathrm{I}$ \\
\hline LY-2979165 & Eli Lilly & Undisclosed & $\begin{array}{l}\text { Bipolar } \\
\text { depression }\end{array}$ & I \\
\hline MCD-386 & Mithridion & M1 agonist & Schizophrenia & I \\
\hline $\begin{array}{l}\text { MGS-0039 (BCI- } \\
\text { 632) }\end{array}$ & Taisho & $\mathrm{mGluR}_{2}$ antagonist & Depression & I \\
\hline NSI-189 & Neuralstem & Undisclosed & Depression & I \\
\hline $\begin{array}{l}\text { Ordopidine (ACR- } \\
325)\end{array}$ & NeuroSearch & Dopamine stabilizer & $\begin{array}{l}\text { Bipolar } \\
\text { depression }\end{array}$ & I \\
\hline PF-04958242 & Pfizer & $\begin{array}{l}\text { AMPA positive } \\
\text { allosteric modulator }\end{array}$ & Schizophrenia & I \\
\hline PF-05180999 & Pfizer & Undisclosed & Schizophrenia & $\mathrm{I}$ \\
\hline R-213129 & $\mathrm{J} \& \mathrm{~J}$ & GlyT $_{1}$ inhibitor & Schizophrenia & I \\
\hline RG-1578 & Roche & mGluR $_{2}$ antagonist & Depression & $\mathrm{I}$ \\
\hline RG-7166 & Roche & $\begin{array}{l}\text { Triple reuptake } \\
\text { inhibitor }\end{array}$ & Depression & I \\
\hline RO-4995819 & Roche & Undisclosed & Depression & I \\
\hline RP-5063 & $\begin{array}{l}\text { Reviva } \\
\text { Pharmaceuticals }\end{array}$ & $\begin{array}{l}\text { 5-HT/dopamine } \\
\text { antagonist }\end{array}$ & Schizophrenia & I \\
\hline SEP-228432 & $\begin{array}{l}\text { Dainippon - } \\
\text { Sumitomo }\end{array}$ & $\begin{array}{l}\text { Norepinephrine, 5- } \\
\text { HT and dopamine } \\
\text { reuptake inhibitor }\end{array}$ & Depression & $\mathrm{I}$ \\
\hline SKL-10406 & SK Holdings & Triple reuptake & Depression & $\mathrm{I}$ \\
\hline
\end{tabular}




\begin{tabular}{|c|c|c|c|c|}
\hline & & inhibitor & & \\
\hline SRX-246 & Azevan & $\mathrm{V}_{1 \mathrm{a}}$ antagonist & Depression & $\mathrm{I}$ \\
\hline SRX-251 & Azevan & $\mathrm{V}_{1 \mathrm{a}}$ antagonist & Depression & $\mathrm{I}$ \\
\hline SYN-114 & Roche & 5- $\mathrm{HT}_{6}$ antagonist & Schizophrenia & $\mathrm{I}$ \\
\hline SYN-120 & $\begin{array}{l}\text { Biotie } \\
\text { Therapeutics }\end{array}$ & 5- $\mathrm{HT}_{6}$ antagonist & Schizophrenia & $\mathrm{I}$ \\
\hline $\begin{array}{l}\text { Vabicaserin (PF- } \\
5208769)\end{array}$ & Pfizer & $5-\mathrm{HT}_{2 \mathrm{C}}$ agonist & Schizophrenia & $\mathrm{I}$ \\
\hline YKP-3089 & SK Holdings & Undisclosed & Anxiety & II \\
\hline
\end{tabular}

